\title{
PEMIKIRAN SAINS-SUFISTIK ORANG BUGIS DALAM NASKAH KUTIKA UGI'SAKKE RUPA
}

\section{BUGINESE SCIENCE-SUFISM IN THE RUTIKA UGI SAKKE RUPA}

\author{
Rahmatia $^{1}$ dan Abdullah Maulani ${ }^{2}$ \\ ${ }^{1}$ Universitas Indonesia, Indonesia \\ ${ }^{2}$ Universitas Islam Negeri Syarif Hidayatullah Jakarta, Indonesia \\ rahmalogi@gmail.com
}

DOI: 10.31291/jlka.v19.i2.935

Diterima: 15 September 2021; Direvisi: 15 Desember 2021;

Diterbitkan: 31 Desember 2021

\begin{abstract}
This article discusses the contents of the manuscript entitled Kutika Ugi Sakke Rupa (KUSR) or Bunga Rampai Kutika Bugis. KUSR explains the method of calculating the good and bad times of the Bugis people. KUSR has a superior value to similar kutika scripts that only contain one or two methods. KUSR collects several methods of calculating time which mostly accepts literature from the Islamic world in the Middle East and North Africa, such as the works of Sheikh Ahmad bin Muhammad Ramadān alMakki and Abu al-'Abbās Ahmad bin 'Alī al-Būnī. In addition, Ibn 'Arabì thought also played an important role in the construction of the KUSR text through the explanation of wahdät al-wujūd understanding and remembrance related to the elements of Islamic Sufism. In this regard, this article analyzes the relationship between the influence of Islamic Sufism and the Kutika method of calculation, especially in the 19th century. Therefore, a philological approach related to the study of texts and the history of manuscripts to understand the background of Islamic influence is an important thing to do in this study. This aims to reveal the form of Islamic influence contained in the KUSR text and its relation to the development of Islam in South Sulawesi. Thus, Islamic discourses, especially Sufism, can be seen as an influential factor in the transmission of science and astronomy in the 19th century Bugis society.
\end{abstract}


Keywords: Kutika, Bugis, Natural Science, Sufism.

\begin{abstract}
ABSTRAK
Artikel ini mendiskusikan isi naskah yang berjudul Kutika Ugi' Sakke Rupa (KUSR) atau Bunga Rampai Kutika Bugis. KUSR menjelaskan metode perhitungan waktu baik dan buruk masyarakat Bugis. KUSR memiliki nilai ungul daripada naskah kutika serupa yang hanya memuat satu atau dua metode. KUSR menghimpun beberapa metode hitungan waktu yang banyak meresepsi literatur-literatur yang berasal dari dunia Islam di Timur Tengah dan Afrika Utara, seperti karya-karya Syekh Ahmad bin Muhammad Ramadhân al-Makki dan Abu al-'Abbas Ahmad bin Ali al-Būn̄i. Selain itu, Ibnu 'Arabī juga memegang peranan penting dalam konstruksi teks KUSR melalui penjelasan paham wahdāt al-wujūd dan zikir-zikir yang berkaitan dengan unsur-unsur sufisme Islam. Sehubungan dengan hal tersebut, artikel ini menganalisis kaitan antara pengaruh sufisme Islam dan metode hitungan Kutika, khususnya pada abad ke-19. Oleh sebab itu, pendekatan Filologi terkait kajian teks dan sejarah naskah untuk memahami latar belakang pengaruh Islam menjadi hal yang penting dilakukan dalam studi ini. Hal ini bertujuan untuk mengungkap bentuk pengaruh Islam yang terdapat dalam naskah KUSR dan kaitannya dengan perkembangan Islam di Sulawesi Selatan. Dengan demikian, wacana-wacana keislaman terutama tasawuf dapat dilihat sebagai faktor yang berpengaruh terhadap transmisi ilmu sains dan falak masyarakat Bugis abad ke-19.
\end{abstract}

Kata kunci: Kutika, Bugis, Sains, Sufisme.

\title{
PENDAHULUAN
}

Islam sudah masuk ke tanah Sulawesi sejak era Raja Gowa X (1546-1565) dengan memberi izin kepada pedagang-pedagang Melayu untuk menetap di Mangalekana (Somba Opu) melalui suratnya kepada Nakhoda Bonang. ${ }^{1}$ Namun, menurut keterangan Noorduyn ${ }^{2}$, belum ada orang Bugis-Makassar yang masuk Islam pada saat itu. Islam resmi menjadi agama kerajaan dan dianut oleh seluruh rakyat Gowa pada 9 November 1607

${ }^{1}$ Mattulada, Menyusuri Jejak Kehadiran Makassar Dalam Sejarah (Yogyakarta: Ombak, 2011), 44.

2J Noorduyn, Een Boeginees Geschriftje over Arung Singkang” Dalam Bijdragen Tot de Taal-, Land- En Volkenkunde (Leiden: KITLV \& Royal Netherlands Institute of Southeast Asian and Caribbean Studies, 1953), 88. 
melalui acara salat Jumat pertama di Masjid Tallo. ${ }^{3}$ Setelah itu, perlahan-lahan Islam menyebar di seluruh penjuru Sulawesi Selatan dan menjadi agama mayoritas yang dianut oleh orang Bugis dan Makassar.

Pesatnya perkembangan Islam sejak resmi menjadi agama yang dianut oleh Kerajaan Gowa-Tallo'pada awal abad ke-17 tidak hanya membawa dampak politik pada kerajaan di sekitarnya, tetapi juga membawa dampak sosial dan budaya pada kawasan Sulawesi Selatan secara luas. Islam dalam ranah sosial dan budaya tampak pada sistem penulisan aksara. Pada masa ini, tradisi tulis orang Bugis yang sudah memiliki aksara lokal, yakni aksara Lontara ${ }^{4}$, banyak dipengaruhi oleh sistem bahasa Arab dan Melayu sehingga tercipta aksara Sérang yang memiliki kemiripan grafem dengan aksara Jawi (Cho Tae Young, 2012: 111). Roger $\mathrm{Tol}^{5}$ mengungkapkan bahwa dalam naskah-naskah Bugis aksara Lontara seringkali ditulis berdampingan dengan aksara Arab atau Latin. Meskipun pengaruh Islam amat kuat sejak abad ke-17, tidak menjadikan aksara Arab mendominasi tradisi tulis di Sulawesi Selatan. Mayoritas orang Bugis mempertahankan aksara Lontara sebagai identitas tradisi tulis mereka meskipun dalam teks-teks Islam.

Dalam perkembangannya, tradisi tulis naskah-naskah Bugis tetap hidup sampai akhir abad ke-19 meskipun teknologi percetakan sudah menyebar luas di penjuru Nusantara. Namun, setelah abad ke-19, tren percetakan ini secara tidak langsung turut andil menggerus tradisi penulisan naskah-naskah Bugis ${ }^{6}$. Meskipun demikian, kuatnya budaya mencatat yang diwarisi

${ }^{3}$ Mattulada, Menyusuri Jejak Kehadiran Makassar Dalam Sejarah, 46.

"Kata 'lontara' merupakan turunan dari kata 'lontar' yang berasal dari Jawa. Lontara' merupakan bagian yang tak terpisahkan dalam transmisi ilmu pengetahuan masyarakat Bugis. Lihat Koolhof "The 'La Galigo'; A Bugis Encyclopedia and Its Growth," Bijdragen Tot de Taal-, Land- En Volkenkunde 155, no. 3 (1999): 362.

${ }^{5}$ Roger Tol, "Bugis Kitab Literature. the Phase-out of a Manuscript Tradition," Journal of Islamic Manuscripts 6, no. 1 (January 1, 2015): 362, https://doi.org/10.1163/1878464X-00601005.

${ }^{6}$ Tol, 70 . 
masyarakat Bugis, memberikan dampak positif selama berabadabad dengan melimpahnya tinggalan catatan-catatan kuno yang dapat dipelajari hingga hari ini. Salah satunya adalah Lontara' Kutika yang merekam jejak peradaban ilmiah manusia Bugis.

Lontara' Kutika dimaknai secara umum sebagai kumpulan catatan waktu baik dan buruk untuk melakukan suatu kegiatan. Namun, Lontara' Kutika tidak hanya memuat berbagai hitungan hari baik dan buruk atau ramalan nasib, tetapi juga prakiraan cuaca dalam bidang pertanian maupun pelayaran (PaEni, 2003: viii). Mattulada ${ }^{7}$ menambahkan kegunaan pau kotika mencakup aspek perhitungan waktu yang luas, yakni meliputi petunjuk waktu untuk memulai pekerjaan di sawah, mendirikan rumah, memasuki rumah baru, dan juga pedoman untuk mengetahui makna mimpi.

Apabila merujuk pada periode awal penelitian mengenai kutika, B.F. Matthes (1868) telah melakukan penelusuran terhadap Lontara' Kutika $^{8}$ dan mendeskripsikan tabel-tabel yang menjelaskan petunjuk hari yang disebutnya kutika lima milik seorang imam bernama Abd' al-Wahhab. Laporan penelitiannya tergolong singkat, yakni berjumlah 38 halaman. Namun, hasil penelitiannya sangat berarti dalam kajian mengenai kutika yang hampir dilupakan oleh para peneliti. Penelitian selanjutnya terkait kutika dilaksanakan oleh Kathryn Robinson ${ }^{9}$ pada tahun 1998 dan Roger Tol $^{10}$ terhadap naskah kutika yang berbentuk gulungan rontal menyerupai pita kaset berukuran besar. Pada periode selanjutnya, penelitian mengenai teks kutika sebagai metode hitungan lokal Bugis telah dikaji melalui beberapa

${ }^{7}$ Mattulada, Latoa, Satu Lukisan Analitis Terhadap Antropologi Politik Orang Bugis (Ujung Pandang: Hasanuddin University Press, 1995), 18-19.

${ }^{8}$ Matthes, B.F. 1868. Makassarsche en Boeginesche Kotika's. Leiden University Libraries: Sutherland

${ }^{9}$ Robinson Kathryn and Mukhlis PaEni, "Living Through Histories: Culture, History and Social Life in South Sulawesi," Journal of Southest Asian Studies 32, no. 03 (1998): 469-72.

${ }^{10}$ Roger Tol, "Rolled up Bugis Stories: Marriage Advice and The Tale of The Parakeet," Review of Indonesian and Malaysian Affairs 43, no. 1 (2009): 189-208. 
pendekatan. Pertama, pendekatan ilmu sain ${ }^{11}$. Penelitian tersebut membandingkan metode penghitungan bulan antara pananrang (kutika) dalam Lontara' dan kalender Hijriah. Kesimpulan dari penelitian tersebut adalah perbedaan penentuan awal bulan disebabkan oleh perbedaan konsep dan kriteria mengenai hilal. Oleh karena itu, diperlukan kriteria imkân alru yah sebagai kriteria hisab-rukyat Indonesia yang disepakati semua pihak.

Penelitian kutika juga pernah dikaji dengan pendekatan ilmu kultural linguistic. ${ }^{12}$ Dengan menggunakan pendekatan kultural lingustik, penelitian tersebut menjelaskan simbol hari baik dan buruk dalam Lontara' Pananrang. Dalam lontara' tersebut, terdapat pedoman hitungan yang dinamakan kutika atau daftar hari baik dan buruk. Simbol-simbol baik dan buruk diilustrasikan melalui jenis binatang, simbol waktu, simbol matematika, dan constellations symbols. Selanjutnya, penelitian kutika dengan pendekatan sejarah dan etnografi ${ }^{13}$. Tulisan tersebut secara komprehensif memberikan penjelasan yang baik mengenai sistem perhitungan hari atau kalender Bugis berdasarkan naskah kutika. Selain itu, dari segi penelitian etnografi, diperoleh kesimpulan bahwa perhitungan waktu dalam masyarakat Bugis tidak hanya digunakan untuk menentukan waktu beribadah, tetapi juga waktu untuk memulai kegiatan pertanian, navigasi pelayaran, dan prediksi cuaca.

Penelitian dalam tulisan ini menganalisis Lontara' Kutika yang ditemukan di Kalimantan Timur, yaitu naskah berjudul Kutika Ugi' Sakke Rupa (KUSR) yang berarti Bunga Rampai Kutika Bugis. Lokasi naskah KUSR yang ditemukan di

${ }^{11}$ Syarifuddin Yusmar, "Penanggalan Bugis-Makassar Dalam Penentuan Awal Bulan Kamariah Menurut Syariah Dan Sains," Jurnal Hunafa 5, no. 3 (2008): 265-86.

${ }^{12}$ Fahmi Gunawan, "Good and Teribble Days Symbols in Pananrang Manuscript: A Cultural Linguistics Approach," in Proceedings 2nd International Seminar on Linguistics (ISOL II) (Padang: Universitas Andalas, 2015), 94-101.

${ }^{13}$ Hasanah, N. dan Suriamihardja. 2016. "Astronomy in BugineseMakassarese Culture Based on Historical and Ethnographical Sources" dalam International Symposium on Sun, Earth, and Life (ISSEL), Jurnal of Physics: IOP Publishing. 
Kalimantan Timur dapat mengindikasikan keberadaan jejak tradisi pengetahuan Bugis di kawasan Melayu. Hal ini berkaitan dengan perjalanan sejarah para pasompe' (perantauan) Bugis yang menyebar di Semenanjung Melayu.

KUSR adalah salah satu naskah koleksi Museum Mulawarman yang dialih digital pada tahun 2019. Berdasarkan kolofonnya, teks KUSR selesai ditulis pada abad 19, yaitu $1311 \mathrm{H}$ atau 1893 M. Pada eksordium naskah, terdapat sebuah surat yang ditulis menggunakan huruf Jawi dan Bugis dan menyebutkan dua tokoh penting pada masa tersebut, yakni Kapitan Abd al-Wahab atau dikenal dengan nama Syekh Abdul Wahhab al-Bugisi dan Ibn Abdul Karim yang dikenal dengan nama Muhammad bin 'Abd al-Karim al-Sammani (Azra, 2018: 321).

Syekh Abdul Wahhab al-Bugisi merupakan ulama keturunan Sulawesi Selatan yang menjadi ulama besar di Kalimantan dan berhubungan erat dengan tarekat Sammaniyah Muhammad Arsyad al-Banjari di Kalimantan. Dengan demikian, KUSR turut memperlihatkan jejak peninggalan manusia Bugis di Kalimantan, khususnya transmisi pengetahuan yang berkaitan erat dengan jaringan ulama Haramayn, Bugis, dan Kalimantan. Selain itu, metode hitungan kutika dalam teks KUSR banyak merujuk pada kitab-kitab ulama Timur Tengah, seperti Ja'far Șadiq, Syekh Ali Mulawi, Saehata I Belawa, Petta Pakie I Sawito, Sayyidī Muhyiddīn Ibn al-'Arabī, Syekh Muhammad Ibn Ali al-Hindi, dan kitab Syamsul Ma'arif karangan Sayyid Ahmad al-Būn̄.

Penjelasan kutika pada naskah KUSR adalah gabungan antara ilmu sains dan tasawuf yang berkaitan erat dengan mistiko-filosofis wahdāt al-wujūd Ibn 'Arabi. Paham wujudiyah dalam KUSR memberikan gambaran bahwa aliran mistik memiliki pengaruh yang kuat dalam periode Islam Melayu-Sulawesi pada masa ini. Penelitian mengenai sufisme di Sulawesi Selatan telah dikaji oleh beberapa peneliti, yaitu Rajab ${ }^{14}$, Ridhwan ${ }^{15}$, dan

${ }^{14}$ Hadarah Rajab, "Implementasi Nilai-Nilai Sufisme Tarekat Naqsabandiyah Di Sulawesi Selatan," Ulumuna: Jurnal Studi Keislaman XIV (2010): 341-68.

${ }^{15}$ Ridhwan, "Development of Tasawuf in South Sulawesi," QIJIS (Qudus International Journal of Islamic Studies) 5 (2017): 29-46. 
Ubaedillah ${ }^{16}$. Ketiga penelitian tersebut secara umum hanya memaparkan jaringan tarekat tertentu pada beberapa daerah di Sulawesi Selatan.

Ketiga penelitian tersebut secara umum hanya memaparkan jaringan tarekat tertentu pada beberapa daerah di Sulawesi Selatan berdasarkan berdasarkan data sosio historis. Di sisi lain, Kajian mengenai kutika, seperti pada penelitian Yusmar, Gunawan, dan Hasanah menitikberatkan penelitian mereka pada konvensi hitungan hari dan tanggal di dalam naskah kutika. Hal ini berbeda dengan penelitian yang mengacu pada kajian teks naskah KUSR ini. Oleh sebab itu, penelitian ini mempertanyakan kembali mengenai kaitan antara metode sains, yaitu hitungan hari berdasarkan peredaran bulan, dan ajaran sufisme yang terdapat di dalam teks KUSR.

Penelitian ini bertujuan untuk mengkaji lebih dalam pengaruh tarekat secara spesifik pada naskah. Hal tersebut dapat mengurai kedua aspek ini, sains dan sufistik, dapat terkoneksi satu sama lain. Dalam konteks ini, sains dimaknai sebagai pengetahuan yang sistematis berdasarkan observasi mengenai fenomena yang diamati secara berulang. Relevansi dari ilmu sains tersebut adalah metode hitungan waktu (kutika) yang dimiliki orang Bugis. Dalam naskah KUSR, metode hitungan waktu dapat dikaitkan dengan mistiko-filosofis wahdah al-wujud Ibn Arabi ${ }^{17}$ dan ilmu tamsil (tanda) yang dijelaskan oleh ahli hikmah abad ke-13, yaitu Sayyid Ahmad al-Būnī (w. 622 H/1224 M).

Penelusuran pemikiran sains-sufisme di dalam penelitian ini karena sumber yang menjadi data penelitian adalah manuskrip berbahasa Bugis yang berjudul Kutika Ugi' Sakke Rupa (KUSR). Oleh sebab itu, diperlukan langkah kerja filologis untuk menganalisis isi teks. Filologi adalah bidang ilmu yang menjadikan naskah dan teks sebagai objek kajiannya dan memiliki tujuan untuk menemukan bentuk teks asli yang dikenal dengan

${ }^{16}$ Achmad Ubaedillah, "The Rise of The Khalwatiyah Samman Sufi Order in South Sulawesi: Encountering The Local, Escaping The Global," Studia Islamika 24 (2017): 213-43.

${ }^{17}$ Azra, Jaringan Ulama Timur Tengah Dan Kepulauan Nusantara Abad XVII Dan XVIII Akar Pembaruan Islam Indonesia, 208. 
kritik teks (Achadiati, 2019: 43). Sehubungan dengan hal tersebut, filologi dipandang sebagai metode untuk menghasilkan sebuah edisi teks yang sesuai dengan prosedur kajian naskah Nusantara (Achadiati, 2019: 53). Edisi teks yang dipilih untuk menyunting naskah KUSR adalah edisi kritis. Tujuan penyuntingan untuk membuka akses pada naskah dan memudahkan teks agar mudah dibaca. Penyusunan edisi dengan melakukan proses alih aksara dari aksara Lontara ke aksara Latin, lalu dilanjutkan ke proses alih bahasa dari bahasa Bugis ke bahasa Indonesia.

Dalam tahap analisis, akan dilakukan penguraian terhadap struktur dan karakteristik sistem perhitungan tradisional di dalam KUSR. Artikel ini juga mengurai sejarah perkembangan Kutika saat Islam masuk di Sulawesi Selatan melalui studi pustaka. Hal ini bertujuan untuk menjelaskan bagaimana pengaruh-pengaruh tarekat yang terdapat dalam naskah Kutika Ugi' Sakke Rupa dan juga beriringan dengan transmisi ilmu pengetahuan bagi masyarakat Bugis pada abad ke-19.

\section{HASIL DAN PEMBAHASAN}

\section{Kutika dan Khazanah Pernaskahan Sulawesi Selatan}

Metode hitungan kutika pada abad ke-19 telah menyatu dengan napas Islam yang diikuti oleh pengaruh beberapa tarekat pada masa itu. Namun, sesungguhnya sistem hitungan tradisional Bugis telah dikenal sekitar abad ke-14 atau jauh sebelumnya. Masa ini terkait dengan perkembangan kerajaan bercorak HinduBuddha dan perkembangan bahasa Sanskerta dan Melayu di Nusantara.

Hal ini terlihat pada penggunaan sistem hitungan Kutika Lima. Matthes ${ }^{18}$ menjelaskan bahwa hitungan ini terdiri dari lima nama, yakni Masoéwara, Kala, Siri, Barahama, dan Bisinong dan masing-masing hari memiliki kualitas baik dan buruk untuk berbagai macam kegiatan. Nama hari tersebut memiliki kesaamaan dengan nama dewa-dewa dalam kepercayaan Hindu, seperti Maheswara, Kala, Sri, dan Brahma. Bahkan,

${ }^{18}$ B F Matthes, Makassarsche En Boeginesche Kotika's (Leiden University Libraries: Sutherland, 1868), 15. 
hitungan pergantian tahun yang dikenal dengan istilah separiyama sama dengan hitungan satu windu, yakni delapan tahun. ${ }^{19}$

Enre ${ }^{20}$ menjelaskan alasan penggunaan istilah dari dua agama (Hindu dan Buddha) tersebut karena bersumber dari daerah lain, yakni kerajaan Majapahit, yang kemudian melakukan kontak dengan masyarakat Sulawesi Selatan melalui jalur perdagangan. Selain itu, pengetahuan tersebut hanya terbatas pada istilah bahasa tanpa diikuti makna filosofisnya. Hal ini menunjukkan bahwa pengaruh Hindu-Buddha di Sulawesi Selatan hanya dipakai untuk memperkaya kosakata yang tidak ada padanannya dalam dalam bahasa Bugis. Proses meminjam dan mencangkokan kata-kata Sanskerta serta sejumlah kecil kata-kata Indo-Arya, pada umumnya tidak mengalami suatu perubahan fonetis. ${ }^{21}$ Kosakata Sanskerta disesuaikan dengan pola bunyi yang lebih mudah diucapkan dalam bahasa Bugis, seperti Wisnu menjadi Bisinong, Maheswara menjadi Masuwara, dan sebagainya.

Istilah kutika yang dikenal di Sulawesi Selatan sebagai kitab perhitungan tradisional manusia Bugis bukanlah sepenuhnya asli dari Sulawesi Selatan. Kutika berasal dari bahasa Sanskerta, yakni krittika. Kemudian diserap oleh bahasa Melayu menjadi ketika, kutika, atau rejang yang berarti pengetahuan atau widya mengenai tenungan dan tilik-menilik yang tidak berdasarkan rasi/zodiak. ${ }^{22}$

Istilah kutika dalam bahasa Bugis memiliki banyak varian berdasarkan daerah atau suku masing-masing, contohnya suku Makassar menyebut kutika dengan istilah pitika, suku Konjo menyebutnya patikai, dan suku Bugis Bone menyebutnya putika.

${ }^{19}$ Andi Palloge Nabba, Sejarah Kerajaan Tanah Bone (Makassar: Yayasan al-Mu'allim Sulawesi Selatan, 2006), 49.

${ }^{20}$ Fachruddin Ambo Enre, Ritumpanna Wélenrénngé, Sebuah Episoda Sastra Bugis Klasik Galigo (Jakarta: Yayasan Obor Indonesia, 1999), 32.

${ }^{21}$ P J Zoetmulder, Kalangwan, Sastra Jawa Kuno Selayang Pandang (Jakarta: Djambatan, 1985), 14.

${ }^{22}$ B.M.Z. Shaharir, "Kosmologi Malayonesia Yang Terungkap Dalam Bahasa Melayu," Jurnal Peradaban 9 (2016): 16. 
Namun, secara umum, dikenal dengan istilah kutika yang bermakna waktu baik dan buruk. Lontara' Kutika senantiasa ditulis berdasarkan pengalaman dan pengamatan yang berulang dalam rentang waktu 50 sampai 100 tahun. Penggunaan naskah ini sangat dinamis terutama untuk menentukan waktu turun sawah dalam tradisi agraris atau pemberangkatan armada perang dan perahu dagang dalam tradisi maritim. ${ }^{23}$

Sama seperti kepercayaan masyarakat Bugis pada hitungan hari berdasarkan kutika ataupun ramalan dari mitologi dan mimpi. Orang Melayu juga percaya pada hitungan hari baik dan buruk, serta kekuatan pada mistisisme yang bersifat simbol, ritual, maupun jimat untuk kekuatan diri (Shaharir, 2014: 3). Berdasarkan hal tersebut, dapat dikatakan bahwa kutika sebagai konsep tidak hanya dimiliki oleh orang Bugis, tetapi juga menyebar di berbagai wilayah yang bersinggungan dengan bahasa Melayu dan Sanskerta. Aspek pembeda antara kutika Melayu dan kutika Bugis terletak pada penerapan atau pedoman dalam perhitungan yang menyesuaikan dengan keadaan geografis serta kondisi sosial kemasyarakatan.

Perkembangan kutika mengalami kemajuan pesat seiring dengan masuknya agama Islam di Sulawesi Selatan. Ilmu perhitungan tradisional yang pada awalnya hanya didasarkan pada kualitas hari beralih mengikuti sistem penanggalan Hijriah. Hitungan hari yang terdiri atas 30 atau 29 hari dalam satu bulan mulai mengikuti konvensi Islam, tetapi tetap disesuaikan dengan sistem bunyi bahasa Bugis. Begitu pula penomoran bahasa Bugis yang tidak memiliki lambang bilangan, dalam perkembangannya mengikuti kaidah lambang bilangan Arab.

Sejak penerimaan Islam pada abad ke-17, orang Bugis dikenal sebagai penganut Islam yang taat. ${ }^{24} \mathrm{Hal}$ ini diperkuat dengan unsur-unsur Islam yang menjadi bagian integral dari sistem kehidupan masyarakat Bugis dengan istilah Sara'

${ }^{23}$ Mukhlis Paeni, Katalog Induk Naskah-Naskah Nusantara; Sulawesi Selatan (Jakarta: Arsip Nasional Republik Indonesia, 2003), ix.

${ }^{24}$ Christian Pelras, Manusia Bugis (Jakarta-Paris: Nalar bekerjasama dengan Forum, Ecole Francaise d'Extreme-Orient (EFEO), 2006), 4. 
(syariat/agama). Menurut Reid ${ }^{25}$, terdapat papaseng (peribaha$\mathrm{sa} /$ pesan) yang menyatakan pura taro maranang, tepura taro sara' (keputusan rakyat bisa saja diubah, tetapi tidak dengan keputusan syariat). Begitu pula dengan pengaruh ajaran ulamaulama Melayu maupun Timur Tengah yang menjadi anreguru di Sulawesi Selatan. Salah satunya adalah Syekh Abdul Wahhab alBugisi yang telah disebutkan sebelumnya. Adapun perhitungan waktu menurut Syekh Abdul Wahhab al-Bugisi, dalam setiap hari terbagi menjadi lima waktu yang memiliki kualitasnya masing-masing. Metode hitungan ini disebut Kutika Pakkita Esso. $^{26}$

\section{Tabel 1.}

Perbandingan nama bulan dan hari menurut tahun Hijriah dan Bugis

\begin{tabular}{|c|c|c|c|}
\hline \multicolumn{2}{|c|}{ Nama Bulan } & \multicolumn{2}{|c|}{ Nama Hari } \\
\hline Islam & Bugis & Islam & Bugis \\
\hline Muharram & Muharrang & Isnaini & Asénéng \\
\hline Șafar & Sappara' & Śulāśā & Salasa’ \\
\hline Rabī'ul awwal & Rabbele' & Arba'̄̄a & Rebba'a \\
\hline & awwala' & & \\
\hline Rabī'ul akhir & $\begin{array}{l}\text { Rabbele' } \\
\text { ahéré }\end{array}$ & Khamis & Kammisi \\
\hline Jumādal ūlā & Jumadele' & Jumu'ah & Juma' \\
\hline & awwala' & & \\
\hline Jumādal ākhir & $\begin{array}{l}\text { Jumadele' } \\
\text { ahéré }\end{array}$ & Sabtu & Sattu \\
\hline Rajab & Rajja’ & Ahad & Aha' \\
\hline Sya’bān & Sabang & & \\
\hline Ramaḍān & Rumallang & & \\
\hline Syawwal & Sawwala' & & \\
\hline Żulqa'idah & Julukaedda & & \\
\hline Zulhijjah & Juluhijja & & \\
\hline
\end{tabular}

${ }^{25}$ Anthony Reid, "Pluralisme Dan Kemajuan Makassar Abad Ke-17," in Kuasa Dan Usaha Di Masyarakat Sulawesi Selatan (Makassar: Ininnawa, 2019), 79.

${ }^{26}$ Muchlis Hadrawi, Assikalaibineng, Kitab Persetubuhan Bugis (Makassar: Ininnawa, 2017), 190. 
Sumber: Lontara' Kutika milik Abdul Karim Karaeng Tutu, Galesong, Takalar.

Waktu baik dan buruk dalam satu hari dibagi menjadi lima, yakni Elé (pagi), Abbuéng (dhuha), Tangngasso (tengah hari), Loro (Zuhur), dan Assara' (Asar). Waktu mallise adalah hari berisi yang artinya sangat baik. Waktu pollebola adalah hari netral dan masih memiliki kualitas baik. Waktu lobbang adalah kosong yang berarti hari buruk. Waktu maddara adalah berdarah yang berarti hari buruk. Waktu uju' adalah jasad yang berarti hari buruk.

\section{Tabel 2.}

Tabel Kutika Pakkita Esso

\begin{tabular}{llllll}
\hline Esso & Elé & Abbuéng & Tangngasso & Loro & Asara' \\
Juma' & Lobbang & Uju & Maddara & pollebola & Malise \\
Sattu & Lobbang & pollebola & Malise & uju & Maddara \\
Aha' & Malise & pollebola & Uju & lobbang & Maddara \\
Sineng & Malise & pollebola & Uju & maddara & Lobbang \\
Salasa & lobbang & Uju & Pollebola & malise & Maddara \\
Araba & Malise & pollebola & Uju & lobbang & Maddara \\
Kamisi & Lobbang & Uju & Maddara & pollebola & Malise \\
\hline \multicolumn{5}{c}{ Sumber: Hadrawi (2017, 190). }
\end{tabular}

Pengaruh Islam pada ilmu pengetahuan tradisional dalam hal ini tidak dapat dipisahkan satu sama lain. Nama-nama hari yang digunakan pada tabel di atas masih mendapatkan pengaruh lokal yang dipercaya membawa dampak tertentu dalam semua kegiatan, terutama dalam bekerja mencari nafkah. Memilih waktu-waktu yang tepat untuk memulai atau melakukan pekerjaan bagi masyarakat Bugis dapat menentukan keberhasilan usahanya, sehingga dicari waktu yang berkualitas mallise (berisi). Selain itu, terdapat pula hitungan nahase' tabbékka pitué nasiuleng yang menunjukkan waktu-waktu nahas yang muncul di setiap bulan. Hari nahas seringkali dikorelasikan dengan terbitnya Muharram yang dianggap memiliki unsur panas (esso 
mapella) ${ }^{27}$ Hal ini menunjukkan pengaruh Islam telah menyatu dalam alam pikiran orang Bugis.

Meminjam istilah Akhmar ${ }^{28}$ mengenai proses Islamisasi Bugis yang telah menjadi satu dengan akar pemikiran orang Bugis, tidak serta merta menghapus nilai-nilai lokal Bugis praIslam. Dalam hal ini, terjadi hubungan saling silang antara Islam dan Bugis sehingga terdapat istilah Bugisisasi Islam ${ }^{29}$, yakni Islam yang berkembang di Sulawesi Selatan tetap mempertahankan nilai-nilai lokal Bugis. Salah satu bentuk Bugisisasi Islam yang terlihat pada teks KUSR adalah tabel hitungan Kutika Lima (KUSR, 22) yang mengkonversi tiga metode yakni Bugis, Sanskerta, dan Islam.

\begin{tabular}{|c|c|c|c|c|c|}
\hline & 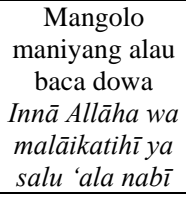 & $\begin{array}{c}\text { Mangolo u[n]rai } \\
\text { maniyang baca } \\
\text { dowa } \\
\text { Qunud }\end{array}$ & $\begin{array}{c}\text { Mangolo alau } \\
\text { manorang baca } \\
\text { dowa } \\
\text { Qulhuwallāhu } \\
\text { ahad }\end{array}$ & $\begin{array}{c}\text { Mangolo u[n]rai } \\
\text { maniyang baca } \\
\text { dowa } \\
\text { Nassrun min } \\
\text { Allāhi wa fathun } \\
\text { qarīb } \\
\end{array}$ & $\begin{array}{c}\text { Manolo } \\
\text { manurengi } \\
\text { baca dowa } \\
\text { Innā a'țaynāka } \\
\text { al-kauthar } \\
\end{array}$ \\
\hline & Seweni & Duwa[m]peni & Tellu[m]peni & Pata[m]peni & Lima[m]peni \\
\hline Iyéle & Masuwara & Kala & Siri & Barhama & Bese’nu \\
\hline Tengessotira & Bese’nu & Masuwara & Kala & Siri & Berhama \\
\hline Tengesso & Berhama & Bese’nu & Masuwara & Kala & Siri \\
\hline Loroi & Siri & Barhama & Bese'nu & Masuwara & Kala \\
\hline \multirow[t]{2}{*}{ Asarai } & Kala & Siri & Barhama & Bese'nu & Masuwara \\
\hline & Raja & Sajata & Laki-laki & Parampuang & Ana'na \\
\hline
\end{tabular}

Dalam tabel Kutika Lima, metode Bugis dipakai untuk menentukan waktu (élé, tengessotira, tengesso, loroi, dan asara'), sedangkan kualitas waktu pada setiap hari memakai istilah Sanskerta yang telah mengalami bugisasi, yakni Masu-

${ }^{27}$ Hadrawi, 192.

${ }^{28}$ Andi Muhammad Akhmar, Islamisasi Bugis: Kajian Sastra Atas La Galigo Versi Bottina I La Déwata Sibawa I Wé Attaweq (Jakarta: Yayasan Pustaka Obor Indonesia, 2018), 2.

${ }^{29}$ Akhmar, 506.

${ }^{30}$ Ayu W Rahmatia, 'Kutika Suku Bugis Di Kalimantan Timur: Kajian Filologi Dan Gagasan Ekofenomenologi', 2020, p. 80. 
wara, Kala, Sri, Barhama, dan Bese'nu. Istilah Islam yang dimaksud dalam tabel ini adalah penentuan arah menghadap ketika akan bepergian disertai dengan bacaan doa yang berbedabeda mulai dari hari pertama sampai hari kelima.

\section{Naskah Kutika Ugi'Sakke Rupa}

Naskah dengan kode PRI/15/MMK/KKT merupakan naskah koleksi Museum Mulawarman di Kalimantan Timur. Naskah didata pada tahun 2019 dengan nomor invertarisasi 07.08 nomor registrasi 1530. Data dalam katalog Sumber-Sumber Tertulis Indonesia Tengah, Kajian Kodikologis, Filologis, Linguistis, Historis, dan Budaya: Kalimantan Timur dan Utara ${ }^{31}$, judul awal naskah adalah Kutika Suku Bugis Bone. Namun, dalam penelitian Rahmatia ${ }^{32}$ (2020), judul tersebut disesuaikan dengan isi naskah menjadi Kutika Ugi' Sakke Rupa (Bunga Rampai Kutika Bugis) yang selanjutnya akan disebut KUSR.

Secara umum, KUSR berisi tabel perhitungan atau kalender untuk menentukan pergantian hari atau bulan. Secara garis besar, isi teks KUSR dapat dikategorikan menjadi tujuh bab yang terdiri atas perhitungan bulan dan waktu; perhitungan dan prediksi untuk segala masalah; pedoman untuk membangun rumah; pedoman untuk membeli perahu; etika dan doa bercocok tanam; dan macam-macam istihara untuk hajat. Dalam satu pembahasan dapat saja diselingi oleh pembahasan lainnya, sehingga tidak terdapat susunan yang jelas untuk setiap bab. Pergantian bab hanya ditandai dengan kata 'pasal' yang diuraikan dalam bentuk narasi.

Manuskrip KUSR telah mengalami perbaikan pada halaman sampul. Sampul naskah berupa sampul yang dilapisi kulit sintetis berwarna hijau. Sampul berukuran $25 \mathrm{x} 18 \mathrm{~cm}$, ukuran halaman 24 x $17,5 \mathrm{~cm}$, dan ukuran blok teks adalah 17 x $10 \mathrm{~cm}$. Jumlah halaman keseluruhan adalah 138 halaman termasuk satu halaman kosong. Nomor halaman naskah ditulis dengan angka

${ }^{31}$ Titik Pudjiastuti, Sumber-Sumber Tertulis Indonesia Tengah, Kajian Kodikologis, Filologis, Linguistis, Historis, Dan Budaya: Kalimantan Timur Dan Utara ((belum diterbitkan), n.d.).

32 Rahmatia, "Kutika Suku Bugis Di Kalimantan Timur: Kajian Filologi Dan Gagasan Ekofenomenologi.” 2020, p. 80. 
Arab pada bagian pias atas dan angka Romawi pada bagian bawah menggunakan pensil. Teks ditulis dari kiri ke kanan dan cara penulisan recto-verso. Eksordium teks KUSR berupa surat yang ditulis menggunakan huruf Jawi dan Bugis.

Ilustrasi berupa gambar-gambar berbentuk simbol dan lambang. Tinta yang digunakan untuk menulis teks berwarna hitam (gambar 1). Terdapat pula rubrikasi dalam naskah ini pada penulisan kompas menggunakan huruf hijaiyah (gambar 2). Pada bagian akhir teks, yakni halaman 137 dan 138, terdapat kolofon yang menyatakan waktu selesainya teks ini ditulis, yaitu pada hari Rabu, 11 Jumadil Akhir $1311 \mathrm{H}$ atau 20 Desember 1893 M dan menyatakan bahwa naskah ini selesai dibuat atas pesanan Haji Mahmud (gambar 3).

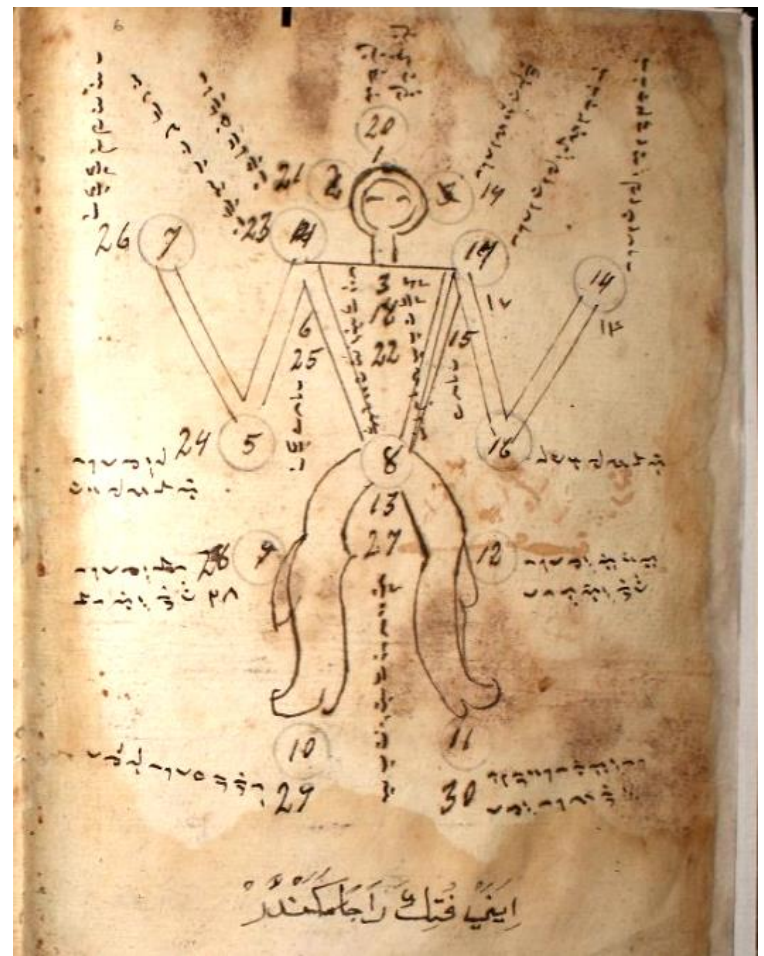

Sumber: Dokumentasi pribadi

\section{Gambar 1.}

Ilustrasi bentuk tubuh manusia (KUSR, 6). 


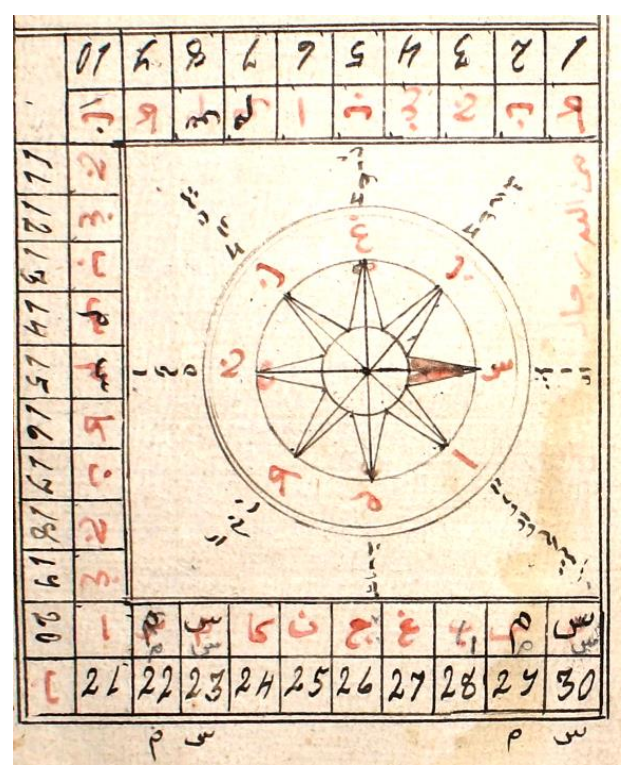

\section{Sumber: Dokumentasi pribadi}

\section{Gambar 2.}

Rubrikasi dalam teks (KUSR, 37).

Kondisi fisik naskah masih baik, tetapi terdapat halaman yang terlepas dan terbalik penempatannya, yaitu halaman 39, 40, dan 60. Namun, hal tersebut tidak menjadi kendala dalam membaca dan memahami isi teks. Sampul, kertas, dan jilidan telah direstorasi. Kertas telah direstorasi dengan kertas Jepang. Penjilidan baru dilakukan oleh Perpustakaan Nasional RI pada tahun 2019.

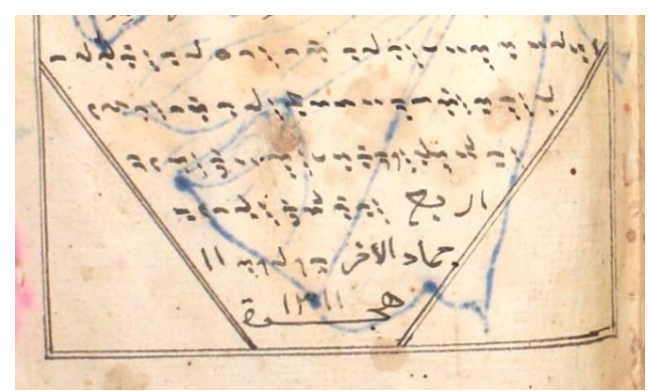

Sumber: Dokumentasi pribadi

\section{Gambar 3.}

Kolofon naskah (KUSR, 138).. 


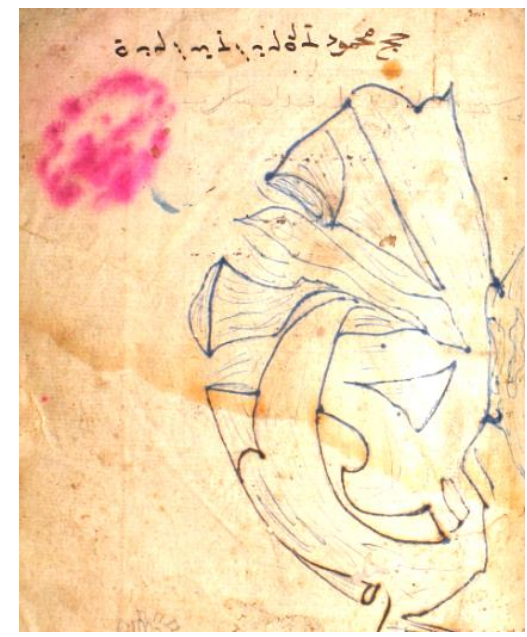

Sumber: Dokumentasi pribadi

\section{Gambar 4.}

Kolofon naskah (KUSR, 137).

Teks KUSR termasuk teks profan. Walaupun sarat dengan bacaan doa dan zikir yang bercirikan pengaruh tarekat tertentu, KUSR tidak dapat dikategorikan sebagai teks sakral. Apalagi naskah ini adalah naskah kompilasi yang tidak berkaitan dengan suatu ritual khusus, misalnya tradisi masure' untuk upacara tanam benih padi. Isi KUSR bersifat umum dan mengandung informasi pengetahuan yang secara general dapat dipraktikkan oleh siapa saja.

Ciri kebahasaan dan aksara di dalam teks KUSR menunjukkan bahwa naskah ini merupakan teks multibahasa dan aksara. Teks KUSR sebagian besar ditulis menggunakan bahasa Bugis. Namun, secara keseluruhan, naskah ini memuat empat bahasa dengan variasi empat aksara, yakni bahasa Bugis dengan aksara lontara', bahasa Bugis dengan aksara sérang, bahasa Arab dengan aksara Arab, bahasa Melayu dengan aksara Jawi, dan bahasa Banjar dengan aksara Jawi. Selain itu, terdapat empat baris catatan kaki yang ditulis menggunakan aksara latin. Namun, aksara Latin tersebut diduga merupakan catatan yang ditambahkan oleh orang lain yang menyimpan naskah ini di kemudian hari. Temuan ini merupakan sesuatu yang jarang terjadi dalam penulisan kitab Lontara'. Hal tersebut menandakan 
luasnya pemahaman penulis teks KUSR terhadap aksara dan bahasa yang dikuasainya.

Bahasa Bugis yang dipakai dalam teks ini tidak dapat secara pasti diklasifikasikan berasal dari salah satu dialek saja. Karena terdapat beberapa dialek bahasa Bugis dalam menyebutkan nama binatang, seperti tikus disebutkan dengan nama balawo (dialek Bugis Bone), walawoi (dialek Bugis Sidrap), bilisu (dialek Bugis Sinjai); kuda disebutkan dengan nama anyarang (dialek Bugis Bone), rusa disebutkan dengan nama jonga (dialek Bugis Bone), jowai (dialek Bugis Sidrap). Terdapat pula bahasa Makassar yang sesekali muncul di dalam teks, seperti kata kuaintu, ritotowaia, dan taungaiya.

Pengaruh bahasa Arab dalam tradisi tulis masyarakat Bugis, terlihat pula di dalam teks KUSR. Penggunaan aksara Arab, Jawi, maupun Serang tersebar di dalam teks KUSR dan dapat dikategorikan menjadi tiga, yaitu nama dan istilah; bacaan doa; dan pola kalimat. Berdasarkan gejala bahasa KUSR yang memuat empat aksara dan empat bahasa di dalamnya, maka kategorisasi ini bertujuan untuk memilah antara teks aksara Arab, Jawi, dan Serang.

Penggunaan aksara Serang dalam kitab Lontara' sangatlah jarang. Hal ini terungkap dalam hasil penelitian PaEni ${ }^{33}$, yang mencatat seluruh hasil microfilm naskah Sulawesi Selatan berjumlah 4049 naskah. Hal tersebut kemudian dirinci oleh Cho Tae Young ${ }^{34}$, yang mendapatkan hasil berupa 780 naskah beraksara Serang dari 4049 naskah. Dengan demikian, persentase naskah beraksara Serang hanya 19,36 persen.

Aksara Serang dalam teks KUSR digunakan sebagai kalimat pembuka atau judul dalam setiap bab dan kadangkala menjadi catatan kaki di luar bingkai teks. Adapun pada bab Hajat Pengasihan ditulis menggunakan aksara Serang dan Arab secara bergantian.

${ }^{33}$ Paeni, Katalog Induk Naskah-Naskah Nusantara; Sulawesi Selatan, xix.

${ }^{34}$ Cho Tae Young, Aksara Serang Dan Perkembangan Tamaddun Islam Di Sulawesi Selatan (Yogyakarta: Ombak Press, 2012), 131. 


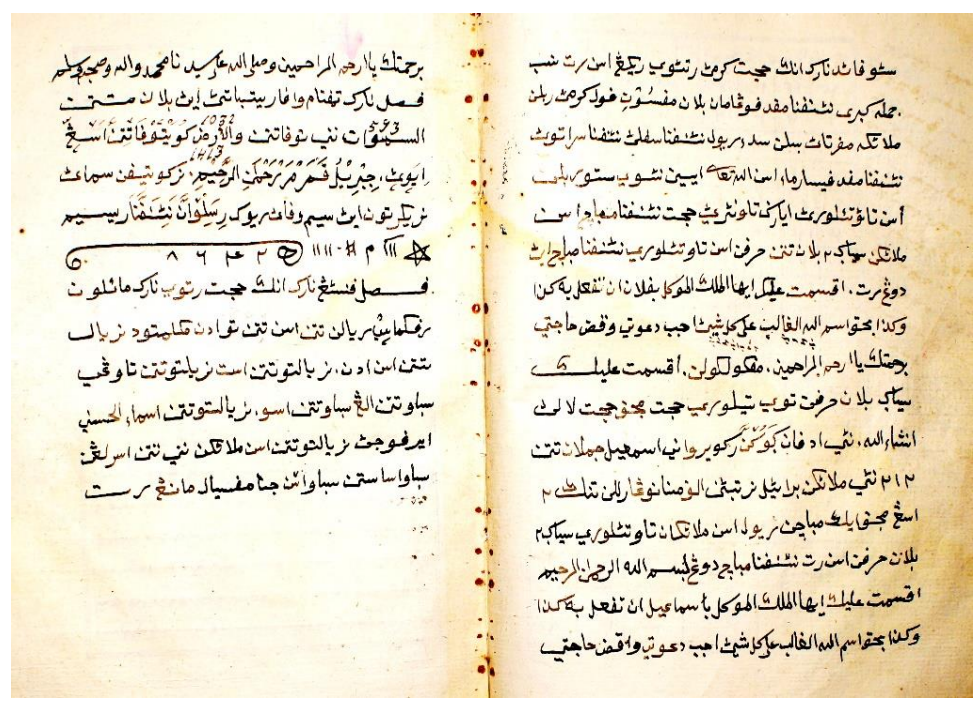

Sumber: Dokumentasi pribadi

\section{Gambar 6.}

Penulisan aksara Serang dalam naskah (KUSR, 108-109).

Untuk melihat pengaruh bahasa Arab yang dikuasai pengarang terhadap teks KUSR yang ditulisnya, hal pertama yang perlu diperhatikan adalah ciri teks Bugis yang menyesuaikan dengan sistem bunyi bahasa lokal. Hal ini jelas terlihat dalam penulisan nama-nama yang berasal dari kosata Arab, seperti Zahra menjadi Isuhura, Yusuf menjadi Yusupu, Nuh menjadi Nohong, dan Namrud menjadi Namarudeng. Begitupun dengan penyebutan nama lokasi yang berasal dari luar Sulawesi, seperti Mesir menjadi Maséré'. Demikian pula pada kata-kata yang terkait dengan ajaran Islam yang ditransfer ke dalam bahasa Bugis, seperti Arsy menjadi Arase', tasbih menjadi bilampilang.

\section{Syekh Abdul Wahhab dan Jaringan Keilmuan Kutika}

Pada halaman awal KUSR, terdapat sebuah surat yang ditulis menggunakan huruf Jawi dan Bugis serta menyebutkan dua tokoh penting pada masa tersebut, yakni Kapitan Abd alWahhab dan di akhir teks terdapat fadilah Alfatiha kepada Ibn Abdul Karim sebagai sumber dari pembuatan tulisan tersebut.

Surat daripada saya Kapitan Abdu al Wahab di Muara Jawa mengabisi seterunya kepada sayal supaya punya orang sendiri 
nama berkawan/ (spasi panjang) supaya dari sini jalan laut fakir/ Sejarah di Muara Jawa Kutai kepada segalal O puwana nyawaku beloné rahasiyaku/ sulomattapana jarena nyawana mataku/ buwana atiku tajénge maréto nana buku/ ita maburané rahasiyaku angolo témangoku nabaddang/Mubari' Ibnu Abdul Karim/ Bifatihah//

(KUSR: 4)

Secara jelas, KUSR tidak menyebutkan bahwa tulisan di dalam kitab ini dibuat oleh Kapitan Abd al-Wahhab. Surat tersebut hanya menyebutkan bahwa seorang kapitan bernama Abd al-Wahhab berada di Muara Jawa Kutai agar ia dapat menjalin persaudaraan. Nama Kapitan Abd al-Wahhab dapat dikaitkan dengan Ince Abdul Wahhab Daeng Masikki yang dikenal sebagai Kapitan Melayu ke-15. Namun, hal ini masih dapat diperdebatkan karena ketidakcocokan masa saat Daeng Masikki diangkat menjadi kapitan oleh pemerintah kolonial Belanda pada tahun $190^{35}$ dan kolofon naskah yang menyebutkan bahwa naskah KUSR selesai ditulis pada tahun $1893 \mathrm{M}$.

Ince Abdul Wahab Daeng Masikki adalah keturunan Melayu yang hidup di Makassar dan mengawali karirnya sebagai guru. Ia pernah menjadi siswa Kweekschool setelah melewati ujian seleksi yang dilakukan oleh B.F. Matthes pada tahun 1879. Ince Abdul Wahab Daeng Masikki dinyatakan lulus pada 1884 dan dilantik menjadi guru bantu di Sekolah Externen, yaitu sekolah rendah yang berhubungan dengan sekolah guru. Ia memperoleh ijazah Diploma dan menjadi guru di sekolahsekolah pribumi yang ada di Sulawesi Selatan (Amir, 2016: 106). Sampai pada tahun 1898, Ince Abdul Wahab Daeng Masikki yang menjadi guru di Segeri dilantik menjadi Jaksa di Takalar, Sulawesi Selatan. Kemudian pada 1 April 1906, ia diangkat menjadi kapitan keturunan Melayu ke-15 berdasarkan surat keputusan Asisten Residen van Senden dalam Regeerings Almanak Kerajaan Hindia-Belanda.

${ }^{35}$ Amrullah Amir, 'Sejarah Masyarakat Melayu di Sulawesi Selatan 1600-1942: Identiti dan Autoriti' (Universiti Kebangsaan Malaysia, 2015), p. 323. 
Berdasarkan pembuka teks, nama Kapitan Abd al-Wahhab di dalam KUSR telah berada di Kutai pada rentang tahun 1893 atau sebelumnya. Apabila nama Abdul Wahab Daeng Masikki dikaitkan dengan pembuka teks, terdapat ketidaksesuaian masa dalam hal ini karena sampai akhir abad ke-19, ia masih menjadi guru dan baru menjadi Kapitan Melayu pada awal abad ke-20. Jabatannya sebagai Kapitan Melayu berarti bertugas untuk memimpin perkampungan Melayu di Makassar berserta urusan administrasinya yang berhubungan dengan pemerintah kolonial. Dapat diperkirakan bahwa maksud eksordium (pembuka teks) naskah KUSR hanya berkisar pada perizinan Kapitan Abd AlWahhab untuk melakukan perjalanan ke Kutai. Namun, sekali lagi, terdapat keraguan yang mendasar mengenai perbedaan angka tahun yang disebutkan di dalam teks KUSR, yakni 1893 dan tahun menjabatnya Abdul Wahab Daeng Masikki sebagai Kapitan Melayu pada tahun 1906.

Frasa 'kapitan', dapat saja merujuk pada seseorang yang menjadi kapten atau pemimpin dalam sebuah pelayaran. Dalam hal ini, dugaan sementara mengarah kepada nama seorang kali atau ulama yang datang ke Kalimantan pada abad awal abad ke19. Dalam jaringan ulama Nusantara ia lebih dikenal dengan nama Abd' al-Wahab al-Bugisi. ${ }^{36}$ Nama al-Bugisi disematkan kepadanya karena Abd' al-Wahab adalah ulama keturunan Sulawesi Selatan yang lazim disebut sebagai orang Bugis. Abd' al-Wahhab al-Bugisi berasal dari keluarga bangsawan yang cukup terpandang di Sulawesi Selatan. Ia adalah seorang putra raja dari tanah Bugis, Sulawesi Selatan, yang bergelar Sadenreng Daeng Bunga Wardiyah (Daudi, 2003: 51).

Dalam karirnya sebagai ulama, Syekh Abdul Wahhab alBugisi lebih banyak mendedikasikan ilmunya untuk perkembangan pusat pendidikan Islam yang didirikannya bersama mertua sekaligus sahabatnya, Syekh Muhammad 'Arsyad di Kaliman$\tan ^{37}$. Syekh Abdul Wahhab al-Bugisi memiliki hubungan persa-

${ }^{36}$ Azyumardi Azra, Jaringan Ulama Timur Tengah Dan Kepulauan Nusantara Abad XVII Dan XVIII Akar Pembaruan Islam Indonesia (Depok: Prenadamedia Group, 2018), 332.

${ }^{37}$ Azra, 332. 
habatan dengan tiga ulama Melayu saat menimba ilmu di Haramayn, yakni Syekh Muhammad Arsyad al-Banjari, Syekh Abdussamad al-Palimbani, dan Syekh Abdurrahman al-Mashri al-Batawi. Adanya hubungan pernikahan Syekh Abdul Wahhab al-Bugisi dengan Syarifah, putri Syekh Muhammad 'Arsyad, semakin memperat hubungan kekerabatan maupun keilmuan antara Sulawesi Selatan dan Kalimantan.

Nama Syekh Abdul Wahhab al-Bugisi telah dikenal sejak sebelum abad ke-19 di Sulawesi Selatan. Melalui catatan Matthes $^{38}$, ia mendapati kutika dari seorang kali (ulama) yang bernama Abdu al-Wahab yang menjelaskan hari nahas dalam satu bulan. Hadrawi ${ }^{39}$ juga menyebutkan hal yang sama, yakni terdapat Lontara' Kutika milik Katte Ummareng yang mengadopsi perhitungan hari ajaran Syekh Abdul Wahhab.Selain kitab kutika yang banyak disalin dan diklaim sebagai ilmu lokal Bugis, belum dapat ditemukan lagi karya tulis yang mencatumkan nama Abdul Wahhab al-Bugisi sebagai pemiliknya. Sampai saat ini, nama Abdul Wahhab al-Bugisi adalah tokoh bayangan yang menyertai perjuangan Syekh Muhammad 'Arsyad al-Banjari ${ }^{40} \mathrm{di}$ Kalimantan.

Minimnya karya yang secara jelas menyebutkan sanad keilmuannya kepada Abd' al-Wahhab al-Bugisi menyulitkan upaya dalam mengidentifikasi pengarang atau sumber ilmu dari KUSR. Namun, penutup surat yang menyatakan bahwa naskah KUSR bersanad kepada Ibn Abdul Karim, "Mubari' Ibnu Abdul Karim" (diciptakan (dari) Ibnu Abdul Karim), adalah hal yang patut diperhatikan. Nama Ibnu Abdul Karim diduga kuat berasal

\footnotetext{
${ }^{38}$ Matthes, Makassarsche En Boeginesche Kotika's, 7.

${ }^{39}$ Hadrawi, Assikalaibineng, Kitab Persetubuhan Bugis, 190.

${ }^{40}$ Syekh Muhammad 'Arsyad al-Banjari merupakan ulama asal
} Kalimantan yang menerima tarekat Sammaniyah dari Ibn Abdul Karim alSamani. Ia dianggap sebagai ulama yang paling bertanggung jawab atas tersebarnya tarekat Sammaniyah di Kalimantan (Azra, 2018, 330). Ia juga menjadi tokoh penting dalam dalam reformasi administrasi keadilan di Kesultanan Banjar dengan menjadikan hukum Islam sebagai acuan dalam pengadilan kriminal. Selain itu, ia juga memperkenalkan jabatan mufti sebagai orang yang mengeluarkan fatwa terkait masalah keagamaan dan sosial (Zamzami 1974, 10-11). 
dari nama pendiri tarekat Sammaniyah, yakni Muhammad bin 'Abd al-Karim al-Sammani. ${ }^{41}$ Ia juga merupakan guru dari Syekh Syekh Muhammad 'Arsyad al-Banjari dan Abd' alWahhab al-Bugisi saat mereka sama-sama belajar di Haramayn.

Dalam melacak identitas pengarang naskah KUSR, sejauh ini terdapat dua kemungkinan. Kemungkinan pertama adalah gelar kapitan yang terdapat di dalam pembuka teks merujuk pada nama Abdul Wahab Daeng Masikki yang menjadi Kapitan Melayu pada masa pemerintahan kolonial Belanda. Kemungkinan kedua adalah istilah kapitan atau kapten merupakan gelar untuk seorang pemimpin pelayaran yang merujuk pada nama seorang ulama, yakni Abd al-Wahhab al-Bugisi yang juga diakui Matthes $^{42}$ dan Hadrawi ${ }^{43}$ sebagai seorang kali atau imam pemilik Lontara' Kutika.

Lokasi ditemukannya naskah KUSR di Kalimantan Timur seirama dengan informasi di dalam teks yang menyebutkan nama tempat 'Muara Jawa Kutai' atau Kutai Kertanegara. Sehubungan dengan hal tersebut, dapat dikatakan bahwa naskah KUSR merupakan bukti adanya jejak keturunan Bugis di Kalimantan. Hal tersebut tidak mengherankan karena hubungan antara Sulawesi Selatan dan Kalimantan telah terjalin sejak awal abad 18. Awal mula keturunan Bugis menyebar di wilayah Kalimantan, ditandai dengan kedatangan seorang bangsawan Bugis keturunan Wajo, yaitu La Madukelleng pada tahun 1720an di wilayah Pasir, Kalimantan Timur. ${ }^{44}$ La Maddukkelleng sering disebut Arung Singkang dan Arung Peneki karena gelar dari orang tuanya. Saat keluar dari Wajo, La Madukelleng hanya berbekal tellu cappa. ${ }^{45}$

${ }^{41}$ Azra, Jaringan Ulama Timur Tengah Dan Kepulauan Nusantara Abad XVII Dan XVIII Akar Pembaruan Islam Indonesia, 321.

${ }^{42}$ Matthes, Makassarsche En Boeginesche Kotika's, 7.

${ }^{43}$ Hadrawi, Assikalaibineng, Kitab Persetubuhan Bugis, 190.

${ }^{44}$ Kathryn Gay Anderson, "The Open Door: Early Modern Wajorese Statecraft and Diaspora" (2003), 140-41.

${ }^{45}$ Noorduyn, Een Boeginees Geschriftje over Arung Singkang” Dalam Bijdragen Tot de Taal-, Land-En Volkenkunde, 144-52. 
Dalam masyarakat Bugis, istilah tellu cappa (tiga ujung) diaplikasikan dalam melakukan proses adaptasi di perantauan. Ujung yang pertama adalah cappa lila yang bermakna ujung lidah, artinya ketika orang Bugis sedang melakukan diplomasi dan negosiasi kerja sama menggunakan bahasa yang santun. Ujung kedua adalah cappa laso yang berarti ujung kelamin, maknanya ketika orang Bugis ingin menyambung tali persaudaraan dengan suku lain, mereka akan menikahi putri raja atau putri bangsawan dan juga putri masyarakat asli di daerah tersebut. Ujung ketiga adalah cappa kawali atau ujung badik, simbol ini bermakna ketika kedua ujung sebelumnya gagal dilakukan, maka ujung badik atau berperang menjadi pilihan terakhir untuk menyelesaikan masalah. filosofi ini senantiasa melekat pada diri pribadi etnis Bugis ke mana pun mereka merantau. ${ }^{46}$

Dalam perantauannya, La Madukelleng menikah dengan puteri Raja Pasir, yaitu Andin Anjang atau Andeng Ajeng, putri dari Aji Geger bin Aji Anom Singa Maulana Sultan Aji Muhammad Alamsyah yang menjadi Raja Pasir pada rentang tahun 1703-1726 M. Selanjutnya, La Madukelleng menjadi Raja Pasir pada tahun 1726 sampai tahun 1736 setelah meredam pemberontakan yang terjadi di Pasir. ${ }^{47}$ Kesuksesan La Madukelleng di tanah rantau begitu cepat menyebar sehingga terjadi gelombang migrasi besar-besaran orang Wajo ke Kalimantan. Kemudian, jaringan diaspora Bugis ini menyebar ke Kutai dan Samarinda yang dipimpin oleh La Mohang Daeng Mangkona. ${ }^{48}$ Jejak pasompe' (perantau) Wajo juga menyebar sampai ke wilayah Kerajaan Banjar dan mendirikan kerajaan bawahan yang dikenal dengan nama Pagatan pada abad ke-18. ${ }^{49}$ Pada masa selanjutnya, para pasompe' Bugis datang ke Kalimantan dengan

${ }^{46}$ Andi Ima Kesuma I.C, Politik Ranjang Bugis Makassar (Makassar: Universitas Negeri Makassar, 2010), 15.

${ }^{47}$ Mansyur, "Diaspora Suku Bugis Di Wilayah Tanah Bumbu, Karesidenan Borneo Bagian Selatan Dan Timur Tahun 1842_1942” (2012), 101 .

${ }^{48}$ Assegaf, Sejarah Kerajaan Sadurangas Atau Kesultanan Pasir (Tanah Grogot: Pemerintah Daerah Tingkat II Pasir, 1992), 123-36.

${ }^{49}$ Anderson, "The Open Door: Early Modern Wajorese Statecraft and Diaspora," 155. 
berbagai tujuan, baik tujuan politik maupun ekonomi. Dalam hubungannya dengan konteks KUSR, para perantau Bugis di Kalimantan Timur dapat dikaitkan dengan jaringan ulama Nusantara yang mulai berkembang sejak abad ke-17.

\section{Resepsi Pemikiran Tokoh-Tokoh Sufi dalam Naskah Kutika Ugi'Sakke Rupa}

Dalam naskah KUSR, metode perhitungan yang digunakan adalah gabungan antara ilmu sains dan tasawuf. Dalam konteks ini, sains dimaknai sebagai pengetahuan yang sistematis berdasarkan observasi mengenai fenomena yang diamati secara berulang. Relevansi dari ilmu sains adalah metode hitungan waktu (kutika) yang dimiliki orang Bugis. Konvensi umum ilmu hitung tradisional dalam kutika, seperti hitungan 30, 9, dan 7 dapat ditemukan di dalam teks KUSR, bahkan terdapat uraian di dalam teks KUSR yang tidak dimiliki oleh teks kutika lainnya, salah satunya adalah penjelasan putika pukulu' jangé yang berkaitan erat dengan mistiko-filosofis wahdah al-wujud Ibn Arabi ${ }^{50}$ dan ilmu tamsil (tanda) yang dijelaskan oleh ahli hikmah abad ke-13, yaitu Sayyid Ahmad al-Būn̄̄ (w. 622 H/1224 M).

Ahmad al-Būnī bernama lengkap Abu al-'Abbas Ahmad bin Ali bin Yusuf al-Qurashi al-Būn̄̄. Nama al-Būn̄̄ ini disematkan karena dia berasal dari Bunnah, Afrika Utara yang kini dikenal sebagai Anabah, Aljazair. ${ }^{51}$ Al-Būn̄i hidup pada masa abad ke-13 (sekitar 1155-1224 M) yang sezaman dengan Muhyidin Ibn al-'Arabī. Oleh sebab itu, karya monumentalnya, yakni kitab Shams al Ma'arif al-Kubra memiliki benang merah dengan pemikiran-pemikiran Ibn al-'Arabī. Selain itu, dalam teks KUSR, terdapat nukilan kitab Shams al-Ma'arif terkait dengan peredaran Naga Lompo (naga besar) dalam satu tahun, seperti kutipan berikut ini.

${ }^{50}$ Azra, Jaringan Ulama Timur Tengah Dan Kepulauan Nusantara Abad XVII Dan XVIII Akar Pembaruan Islam Indonesia, 208.

${ }^{51}$ Noah D. Gardiner, "Esotericism in a Manuscript Culture: Ahmad AlBuni and His Readers Through the Mamluk Period" (University of Michigan, 2014), 71. 
“...Lyana bicaranna angolonna naga lopoél Pasal panessaéngngi a'gulilinna naga lopoé mo(n)roi ri tanaé/ weka eppamigiling nasitaung... makunniro bicaranna naga lopoé masué ri kitta' Syamsul Ma'arif..."

“...Inilah pembicaraan tentang menghadapnya naga besar/ Pasal yang menjelaskan berputarnya naga besar yang tinggal di tanah/ empat kali ia berputar dalam setahun... Demikianlah ceritanya naga besar yang diambil dari kitab Syamsul Ma'arif..."

(KUSR: 60-61)

Ajaran tarekat yang secara samar tertulis dalam KUSR tidak terlepas dari sejumlah pengaruh ulama Timur Tengah maupun ulama Bugis. Melalui karya-karya ulama jaringan Timur Tengah dan dengan pengetahuan penulis KUSR, naskah ini menjelma menjadi transmiter antara ilmu sains dan tasawuf. Terdapat sejumlah nama cendekiawan muslim baik yang berasal dari Timur Tengah maupun lokal Bugis yang metodenya dikutip sebagai pedoman sistem hitungan di dalam KUSR, yaitu Abd alWahhab dan Ibnu Abdul Karim, Ja'far Șadiq, Syekh Ali Mulawi, Saehata I Belawa, Petta Pakie I Sawito, Sayyidī Muhyiddīn Ibn al-'Arabī, Syekh Muhammad Ibn Ali al-Hindi, dan kitab Syamsul Ma'arif karangan Sayyid Ahmad al-Būn̄̄.

Memetakan pengaruh tarekat di dalam KUSR dapat dimulai dari nama-nama ulama yang disebutkan di dalam teks. Terdapat tiga nama penting yang saling berkaitan, yakni Abd' alWahhab al-Bugisi, Ibnu Abdul Karim al-Sammani, dan Sayyidī Muhyiddīn Ibn al-'Arabī. Dalam pembuka teks berdasarkan nama Kapitan Abd al-Wahhab yang menyebutkan bahwa sumber tulisan ini dibuat (mubari') oleh Ibnu Abdul Karim. Telah dijelaskan sebelumnya bahwa dugaan Kapitan Abd al-Wahhab bernama lengkap Abdul Wahhab al-Bugisi yang dalam sanad keilmuannya, berguru pada salah satu sosok pendiri tarekat Sammaniyah, yaitu Muhammad bin 'Abd al-Karim al-Qadiri asSammani (van Bruinessen, 1995: 57) yang lebih dikenal dengan nama Syekh Muhammad Samman ${ }^{52}$.

${ }^{52}$ Ia merupakan pendiri Tarekat Sammaniyah. Tarekat ini merupakan gabungan dari berbagai metode dan bacaan-bacaan dari tarekat lain, yaitu 
Teks KUSR juga mengutip periwayatan dari Ja'far Șadiq untuk menjelaskan keistimewaan hari dalam membeli pakaian. Hal ini tampak dalam kutipan berikut.

Pasal makkedai nabita Musal niginigi maccorikengngi pakéyangngé riyaso Jumu'ah/ manenungeng sau ininawa/ niginigi maccorikengngi pakéyang riyaso Khamis/ a(ng)kai majapo manenungeng pakél niginigi maccorikengngi pakéyang riyaso Arba'a/ lolong arajang nenniya akarang/niginigi maccorikengngi pakéyang riyaso Ślasial manengnge malasa pakéi/ niginigi maccorikengngi pakéyang riyaso Isnaini/ dénakenai lasatalaleng/ niginigi maccorikengngi pakéyang riyaso Ahad/ napakéyang maté pakéyannal niginigi maccorikengi pakéyang riyaso Sabtu/ manenunge masara ininawa/ Ja'far Shadiq.

Terjemah: Pasal berkatanya Nabi Musa a.s/ Barang siapa membeli pakaian di hari Jumat/ ia akan menjadi orang cerdas selama (memakai pakaian itu)/ Barang siapa membeli pakaian di hari Kamis/ maka ia tidak akan menemukan kebaikan selama memakainya/ Barang siapa membeli pakaian di hari Rabu/ disertakan untuknya kebesaran dan juga terangkat (derajatnya)/ Barang siapa membeli pakaian di hari Selasa/ sepanjang baju itu dipakai dia akan sakit/ Barang siapa membeli pakaian di hari Senin/ dia tidak akan terserang penyakit dalam (penyakit serius)/ Barang siapa membeli pakaian di hari Minggu/ dibawa sampai mati pakaiannya/ Barang siapa membeli pakaian di hari Sabtu/ selama baju itu dipakai, dia akan selalu gelisah/Ja'far Shadiq//

(KUSR: 18)

Selain Ja'far Sadiq, teks KUSR juga meresepsi pemikiran Syekh 'Āli Mulawi. Disebutkan bahwa ia berasal dari Mesir dan mengajar di Makkah. Hal ini tergambar dalam kutipan berikut.

Khalwatiyah, Qadiriyah, Naqsyabandiyah, dan Syaziliyah (Nurhata, 2011: 6). Di Nusantara, tarekat ini pernah mendapatkan pengikut massal, yang persebarannya dimulai pada akhir abad delapan belas (van Bruinessen, 1995: 55). Tarekat ini sangat merakyat di daerah Sumatera Barat dan Kalimantan Selatan. Salah satu tokoh tarekat Sammaniyah yang berpengaruh di Kalimantan adalah Muhammad 'Arsyad bin 'Abd Allah al-Banjari, sahabat sekaligus mertua Abdul Wahhab al-Bugisi (Azra, 2018: 330). 
Pasal \{iyanae\} asetihara so(m)pe'reng masenna makasing ipakél narékko maléoki so(m)pe' narékéngi tetinna asseng riyaléta' enrengé tetinna asenna wanuwa maélo tasuri e(n)rengé tetinna esso mélo 'é tajeppa hurupu'na abjad ipaké/ muinapanna buwa tatellui/ narékko si'di le[ng]bbina matettui sidupa pagoraé yiréga teléngi lopié yiréga repai yiréga natujuki lasa marajal narékko 2 duwa lebbina majaatto réwéku masesakalé masusa marajal narékko genne" tatoli'i majeppu e(ng)kai asapareta mabarakka lolongettoi dalé mabarakka naripalowang tetong ri puwang Allah Ta'ala sinina haja'na/ makunniro isetihara napakéwé a(n)réguruta riyasengé Syeikh Ali Mulawi/ Maséréé wanuwa Hawiya asenna ka(m)ponnal mo(n)roé ri tana Mekka tulimappangaji rilalena Masejidile Marama/ talitutuiwi menapakéi narékko maéloki so(m)pe' nasaba barakena nabita/ salamakki/wallahu 'alam//

Terjemah: Inilah pesan yang baik dipakai untuk perjalanan mencari rezeki/ Jika ingin melakukan perjalanan, maka hitunglah titik nama yang pada dirimu juga titiknya nama negeri yang akan didatangi juga titiknya hari yang akan dipakai untuk berangkat dengan huruf abjad yang dipakai/ kemudian bagi tiga/ Jika satu lebihnya, tentu juga bertemu atau juga akan tenggelam kapalnya atau juga pecah (kapalnya) atau juga kamu akan terkena penyakit besar/ Jika dua lebihnya, (tandanya) tidak baik, kembalilah kamu, nanti akan menyesal karena ada kesusahan besar/ Jika genap yang tertulis, pasti akan ditemukan apa yang dicari itu dan berkah akan didapat juga rezeki yang berkah, dikabulkan hajatnya oleh Allah swt./ Demikianlah pesan yang dipakai guru kita yang bernama Syeikh Ali Mulawi/ negerinya bernama Mesir, dari daerah Hawiya/ Ia tinggal di tanah Makkah yang mengajar mengaji di dalam Masjidil Haram/ Berhatihatilah memakainya jika ingin bepergian sebab berkahnya nabi Muhammad saw./ Selamat/ dan kepada Allah Swt. pengetahuan itu (dikembalikan)//

(KUSR: 35)

Kalimat doa dalam naskah KUSR juga merujuk pada Saehata I Belawa atau disebut juga Sayyid Jamaluddin al-Akbari al-Husaini (hidup sekitar 1310 M). Ia diketahui makamnya berada di Tosora, Wajo, Sulawesi Selatan. 
Pasal \{iyanaé\} dowana wali mapéengilino riyasengi Rijalulu Gaiba ibaca narékko mapangujuki/ Bismillāhirrahmannirrahīm assallāmu'alaikum yā Rijalul Gaibi, assallamuālaikum ya arwahil muqadasatiya a'inūn̄̄ bigauśati illahi wa anzurni

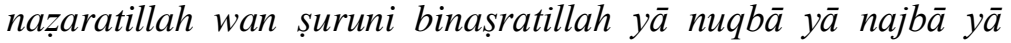
abdālu yā awtādu yā atqiyā' yā gausंu yā quțbu a 'inūni fill aṣril lażi qașadta bihurmati muhammadin șalallāhu alaihi wasallama syaisu lillāhi alfātiha/ nayigaukena Rijalulu Gaibe narékko maéloki laowangi ri bacangi patéha nyawana nabita siseng/ muniyakeni muwalasa(n)réso muwaka niajému wékkapetu muinapatu béréselengiwi nyawana Rijalulu Gaibel narékko purani mapanguju ati(n)rono pégipégi/ Rijalulu Gaiba kotono manga(n)ro aja'muéwai siolo/ narékko muwakani ajému itani aguli'na Rijalulu Gaibe yitona muolail salama' baraka'na Saehata iBelawal

Inilah pasal doanya para wali yang menjaga bumi yang disebut Rijalul Gaib, dibaca jika akan menghadapnya/ Bismillāhirrahmannirrahīm assallāmu'alaikum yā Rijalul Gaibi, assallamuālaikum yā arwahil muqaddasatiya a'inūn̄̄ bigausati illahi wa anzurni nazaratillah wan șuruni binașratillah yā nuqbā yā najbā

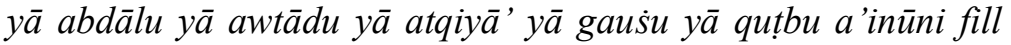
așril lażi qașadta bihurmati muhammadin șalallāhu alaihi wasallama syaišu lillāhi alfātiha/ Kemudian melakukan Rijalul Gaib jika ingin bepergian dengan membaca surah Fatiha satu kali sebagai nyawanya nabi Muhammad saw./ Diniatkan untuk memanggil (tawasul), kemudian melangkah tujuh kali kemudian kamu memberi salam kepada nyawanya Rijalul Gaib/ Jika sudah menghadap, maka berkemaslah untuk pergi/ di mana posisi Rijalul Gaib, disanalah kamu berdoa dan jangan sampai kamu berlawanan arah (membelakanginya)/ Jika setelah kamu melangkahkan kaki, lalu lihatlah (arah) Rijalul Gaib dengan menengok ke belakang, itu pula yang kamu lewati/ Selamat atas keberkahan syekh kita di Belawa.

(KUSR: 36)

Selain beberapa doa dan ketentuan para ulama di atas, KUSR juga mengutip penjelasan tentang paham wahdat alwujud oleh Muhyiddīn Ibn al-'Arabī. Konsep wahdat al-wujud 
dihadirkan untuk menegaskan bahwa konsep ini tidaklah sesat sebagaimana konflik yang terjadi di Aceh pada abad ke-16. Konsep ini tergambar secara praktis dalam kutipan berikut.

Hażā jadwalul Syaikhul Ma'ārif billahi ta'āla Sayyid̄̄ Muhyiddīn Ibn Al-'Arabī, an alkabr baytil ahamu fi śālaśā wa isyruna șahfah wa fi kuli șaf̣atun mi'atun wa situna khānal wajami'u mā fì kuli șaf̣hati khamsa ayātin minal qur'anil aẓim wal 'ayatu swa salasina harfan wakaifiyati tarkibi kuli 'ayatin min ayyi șaf̣atin iża ardatan/ yanz̧urlaka sūratal ikhlasi salaṡa marātin wa fātihatul kitābi maratan wa tuhd̄̄ syawābżalika ilā haḍaratin nabi șalallāhu 'alaihissalam/ wataqra'u fātihatil kitābi maratan ukhrā watuhd̄̄ syawābahā ilāl mu'alifi Sayyid̄̄ Muhyiddīn Ibn Al- 'Arabī / wa tugmiḍu 'ainika watad' u aṣbu'uka alā ayi harfin minhā/ fakhużuhu wa kulu harfin hamisun ba'dahu ilā akhiril șafhati suma tarji'u ilā awalahā wa taf'ala każalika ilā tașila ayil hurufil lażi wa ḍa'at aṣba'uka 'alaihil fatanzuru ayatan yaz̧haru minhā mā yadulu alā murādihi gairihi mujarabin/

Inilah tabel yang dibuat oleh Syekh Ma'ārif Sayyid Muhyiddīn Ibn Al-'Arabī karena Allah ta'ala yang bagian besarnya melingkupi 23 lembar dan di setiap lembar terdapat 160 khatan (tunjuk)/ Dalam semua lembar terdapat masing-masing 5 ayat dari Al-Qur'an dan ayat itu terdiri atas 32 huruf/ Dan bagaimana cara menyusun setiap ayat dari lembaran itu bila kamu berkeinginan mengetahuinya/ Maka bukalah surah Al-Ikhlas lalu baca sebanyak tiga kali dan surah Fatiha satu kali yang ditujukan fadilahnya kepada nabi Muhammad s.a.w/ Kemudian bacalah surah Fatiha sekali lagi dan sampaikan fadilahnya kepada penyusun kitab ini, yaitu Sayyid Muhyyiddīn Ibn Al-'Arabī/ Dan usaplah matamu dan juga wajahmu seakan-akan surahsurah itu merasukimu/ Maka ambila lima setelahnya sampai pada yang terakhir lalu kembali pada yang pertama dan kerjakan lagi seperti itu sampai pada huruf-huruf yang kamu letakkan di wajahmu tadi dengan sangat khusyuk/ Maka kamu akan mengetahui setiap ayat (tanda) yang nampak darinya dan begitulah yang mujarab/

(KUSR: 97) 
Syekh Ahmad al-Marzuki juga menjadi salah satu ulama yang dikutip pengamalan doanya dalam naskah KUSR.

Iyana bicaranna tinpa korangi/ pasal \{iyanaé\}145 yisetihara pole ri Saéha Ahmad al Marzuki/ agiagi hajata tapogauni riolonayi gaukenna tomasembajang duwa raka taniyakengi isetiharal tapangi puresi ri lalenna raka ri oleo imu(n)ri pateha Qul yā ayuhal kafirun laturicappa'na/ tapangi puresi ri lelenna raka ri mu(n)rié imu(n)ri pateha Qulhuwallāh laturicappa'na/ narékko purani mabéréseleng bacani salawa pegipegi salawa ribaca seratu'/ tainapasi toba' seratu' \{iyanaé\}146 astagfirullāhal aẓim/ tainapana bacai weka pitu makuling yinaya innal tasyabaha alaina wa inna insyāllāhu lāmuhtadun/tainapana bacai \{iyaé\}147 dowange siseng laturicappa'na Allāhumma ini astahiruka bi'ilmika wa astaqdiruka biqudratika waas'aluka min fậlikalaz̄im faa innaka taqdirū wala aqdiru wata'lamu walā a'lamu wa anta 'alamul guyub allahuma in kunta ta'lamu ana hażal amra khairun lì fidīni wa dunyā wa ma'asyi wa'āqibati amrī wa'ajilihi wa'ajilihi fa qadruhuli wa yasarihu lì summa barik li fihi yakarimu fâ'inkunta ta'lamu anna hażal amra syaran l̄ fidīni wadunyā// 133 wa ma'āsȳ̄ wa 'aqibatan amrī wa 'ājilihi fașrifhu wa șarifniya 'anhu waqadru lil khaira khaisu kāna suma raḍin̄ bihi biraḥmatika yā arhamarrāḥimīn//

Inilah bicaranya tentang membuka Alquran/ inilah pasal istihara yang datang dari Syekh Ahmad al Marzuki/ untuk apapun yang dihajatkan, maka terlebih dahulu kerjakan solat dua rakaat diniatkan istiharah/ setelah itu, sesudah surah Fatiha dalam rakaat pertama baca surat Al-Kafirun sampai selesai/ setelah itu, setelah surah Fatiha dalam rakaat kedua, baca surat Al-Ikhlas sampai selesai/ Jika selesai salam bacalah selawat, selawat apapun dibaca $100 \mathrm{kali} / \mathrm{kemudian}$ istigfar, yaitu astagfirullāhal aẓim, $100 \mathrm{kali} / \mathrm{kemudian}$ baca sebanyak tujuh kali, yaitu innal tasyabaha alaina wa inna insyāllāhu lāmuhtadun/ kemudian baca doa ini satu kali sampai habis, Allāhumma ini astahiruka bi'ilmika wa astaqdiruka biqudratika waas'aluka min fadlikalaz̄ìm faa innaka taqdirū walā aqdiru wata'lamu walà a'lamu wa anta 'alamul guyub allahuma in kunta ta'lamu ana hażal amra khairun lì fidīni wa dunyā wa ma'asyi wa'āqibati amrī wa'ajilihi wa'ajilihi fa qadruhuli wa yasarihu lì summa barik li 
[133] fihi yakarìmu fá 'inkunta ta'lamu anna hażal amra syaran lì fidīni wadunyāl/ wa ma'āsȳ̄ wa 'aqibatan amrī wa 'ājilihi fașrifhu wa șarifniya 'anhu waqadru lil khaira khaisu kāna sंuma rạ̣inī bihi biraḥmatika yā arhamarrāhịimīn

(KUSR: 132)

Syekh Ahmad bin Muhammad Ramadhân bin Manshûr alMakki al-Marzûki al-Mâliki al-Husaini al-Hasani merupakan salah satu ulama terkemuka, mufti mazhab Maliki di Makkah. Meskipun ia membangun karir kecendekiaannya di Tanah Haram, ia berasal dari Mesir yang lahir pada tahun 1205 H/1834 M. ${ }^{53}$ Salah satu karyanya yang populer di Indonesia adalah 'Aqidat al-'Awam. Kitab ini banyak dipelajari di berbagai lembaga pendidikan Islam di Indonesia terutama pesantren. ${ }^{54}$ Sebagai teks yang mendapat pengaruh Islam yang kuat, tak heran jika KUSR juga mengutip doa dari salah seorang ulama yang karyanya amat populer di Nusantara itu.

\section{Naskah KUSR sebagai Transmisi Pengetahuan Sains-Sufistik}

Sistem perhitungan kutika pada abad ke-19 lebih banyak dipengaruhi oleh ilmu sains Islam. Dalam khazanah ilmu perhitungan Islam terdapat beberapa istilah yang merujuk pada 'ilm an-nujūm (ilmu perbintangan), 'ilm hai'ah al-'ālam (ilmu keadaan alam), al-asthrūnimiy $\bar{a}$ (astronomi), dan 'ilm al-falak (ilmu falak). ${ }^{55}$ Ilmu falak berasal dari kata fa-la-ka yang bermakna orbit atau edar benda-benda langit sedangkan definisi umum ilmu falak adalah suatu cabang pengetahuan yang mengkaji

${ }^{53}$ Hishām al-Kāmil Hāmid Mūsā, Fatḥ Al- 'Allām Bi Sharḥ Manzūmati 'Aqīdati Al- 'Awwām (Cairo: Dār el-Manār, 2013), 11.

${ }^{54}$ Informasi ini dapat dibaca juga dalam Amien Nurhakim. 2020. Mengenal Kitab Aqidatul Awam, Syair Ringkas Ilmu Tauhid.

https://www.nu.or.id/post/read/119180/mengenal-kitab-aqidatul-awam-syair-ringkas-ilmu-tauhid. Diakses pada 16 Maret 2021.

${ }^{55}$ Abdul Amir Al-Mu'min, At-Turats Al-Falaky 'Inda a'-Arab Wa Al Muslimin Wa Atsaruhu Fi Ilm Al-Falak Al-Hadits (Aleppo: Universitas Aleppo, 1991), 18. 
keadaan benda langit dari segi bentuk, kadar, kualitas, posisi, dan geraknya. ${ }^{56}$

Sistem perhitungan kutika pada abad ke-19 lebih banyak dipengaruhi oleh ilmu sains Islam. Salah satunya adalah pemikiran-pemikiran Ibn 'Arabi. Melalui realitas esensial heliosentrisisme dalam bangunan dalam kosmologinya, Ibn 'Arabi menetapkan matahari yang dibandingkan dengan Qutb (Kutub) dan Qalb al-alam (inti dunia). ${ }^{57} \mathrm{Hal}$ ini sejalan dengan penjelasan Kutub Mudāwī al-Kulūm tentang rahasia pergerakan orbit yang berhubungan dengan ma'rifah sifat Allah Swt dan keberadaan alAbdal (para pejaga kutub) dalam kitab Al-Futūhăt AlMakkiyah. ${ }^{58}$ Konsep al-Abdal disebutkan dalam teks KUSR sebagai Rijāl al-Gaib.

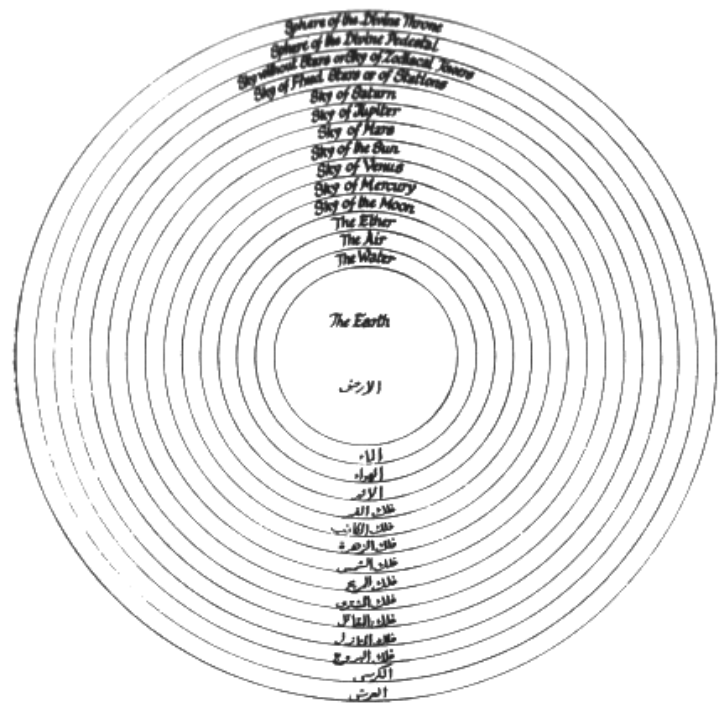

Sumber: Burckhardt (2001, 13).

\section{Gambar 6.}

Hierarki langit inferior dan superior terhadap Matahari

${ }^{56}$ Arwin Juli Rakhmadi Butar-Butar, Filologi Astronomi (Purwokerto: UMP Press, 2017), 11.

57 Titus Burckhardt, Mystical Astrology According to Ibn 'Arabi (Louisville: Fons Vitae., 2001), 21.

${ }^{58}$ Muhyiddin Ibn al-'Arabi, Al-Futuhat Al-Makkiyah Jilid II, ed. Harun Nur Rosyid (Yogyakarta: Darul Futuhat, 2018), 377. 
Gambar di atas adalah tingkatan kualitas langit mulai dari yang terdekat hingga yang terjauh dari bumi dan matahari. Nama planet, seperti mars (al-Marih), Jupiter (al-Musytari), Saturnus (al-zuhal), dan lain sebagainya, terdapat pula dalam teks KUSR. Gambar 7 tersebut dikonversi menjadi tabel dan disebut oleh penulis teks KUSR sebagai metode waktu perputaran jam atau Putika Pukulu' Jangé (KUSR, 31). Namun, dalam tradisi lisan masyarakat Bugis, khususnya Sinjai, tabel Putika Pukulu' Jangé seringkali dikaitkan dengan ilmu falak Imam Ja'far Șadiq.

Ja'far bin Muhammad al-Ṣadiq adalah cucu Ali Zain alAbidin yang dikenal sebagai anak Husein bin Ali bin Abu Thalib. Imam Ja'far Șadiq dipercaya pernah hidup di Sulawesi Selatan mengajarkan ilmu-ilmu pada masyarakat Sulawesi Selatan. ${ }^{59}$ Apabila merujuk pada rentang kehidupan imam yang hidup pada abad ke-8 ini, kemungkinan yang dapat ditelaah adalah ilmunya tetap terjaga melalui pengajaran dari ulamaulama Qadiriyah asal Bira pada abad ke-17. ${ }^{60} \mathrm{Hal}$ ini dapat pula dilihat melalui silsilah keilmuan yang berasal dari cabang Imam Ja'far Șadiq (mahzab Ja'fari) yang dituliskan Syekh Yusuf saat ia dibaiat dalam tarekat Shatariyya dan Qadiriyya bersama dengan Ibrahim Barat al Haq Khutba Bulo-bulo. ${ }^{61}$ Namun, dalam teks KUSR sanad ilmu Imam Ja'far Șadiq secara jelas hanya tercantum untuk satu perkara, yakni hari baik dan buruk ketika akan membeli pakaian.

Apabila merujuk pada teks, kaitan beberapa tarekat ini dapat diidentifikasi melalui bacaan doa maupun zikir dalam teks KUSR. Kalimat zikir seperti laillahailallāhu merupakan keseluruhan dari ajaran Islam, yakni pengakuan tentang keesaan Tuhan (tauhid). Bagi muslim, tauhid ini adalah poros yang jelas dan sederhana dari agama Islam, sedangkan bagi para sufi, kalimat penegasan itu adalah pintu yang terbuka untuk memahami dan masuk dalam realitas esensial (Burckhardt, 1981:69). Selain itu,

${ }^{59}$ Wawancara dengan Muhammad Rauf, 22 Januari 2020.

${ }^{60}$ Thomas Gibson, Narasi Islam Dan Otoritas Di Asia Tenggara Abad Ke-16 Hingga Abad Ke-21 (Makassar: Ininnawa, 2012), 69.

${ }^{61}$ Hamid Abu, Syekh Yusuf: Seorang Ulama, Sufi, Dan Pejuang (Jakarta: Yayasan Pustaka Obor Indonesia, 1994), 360-63. 
zikir simbol, seperti ' $h u w a$ ', ' $a$ ', dan ' $a$ ' dalam dunia tarekat sangat diperlukan. ${ }^{62}$

Simbolisme dalam dunia tasawuf adalah sesuatu yang penting, karena alam semesta berbicara kepada mereka dalam bahasa simbol, dan segala sesuatu juga memiliki signifikansi simbolik disamping nilai eksternalnya. ${ }^{63}$ Zikir simbol Huwa dan $A h$ menyiratkan dzikir dari tarekat tertentu. Menurut Nurhatta (2011: 88) zikir Huwa adalah ciri tarekat Qadiriyah dan zikir $A h$ adalah ciri tarekat Khalwatiyah. Kedua zikir simbol ini juga terdapat dalam teks KUSR, yakni pada halaman 66 yang berbunyi "mupowadasi weka tellu laillahailallāhu muḥammadarrasulullāhi 3 Allāhu 3 huwa huwa 3" (kemudian kamu ucapkan ini sebanyak tiga kali laillahailallāhu muhammadarrasulullāhi, Allāhu sebanyak tiga kali, dan huwa huwa sebanyak tiga kali) dan zikir $A h A h A h$ terdapat dalam tabel halaman 99 dalam menjelaskan kualitas waktu Putika Pukulu' Jangé.

Zikir simbolik dapat ditemukan pula pada teks KUSR halaman 109 dalam menuliskan jimat dengan aksara Arab 111 (a, i, u). Dalam mistik Bugis, bacaan ini dikenal dengan istilah sadda telué (suara yang tiga) (Akhmar, 2018: 474). Sadda telué disebut juga syahada' simula-mulanna lino atau syahadat pada saat pertama kali bumi diciptakan. Dalam mistik Bugis suara tersebut dipahami sebagai suara yang tidak terucapkan oleh lidah dan tak dihembus oleh angin atau tennaleppa' lila, tennairi' anging. Vokal /a/, /i/, dan /u/ adalah suara yang diucapkan oleh bayi saat pertama kali keluar dari rahim ibunya. ${ }^{64}$

Penggunaan vokal Sadda telué adalah simbol yang menunjukkan relasi antara Tuhan melalui vokal /a/, diri melalui

${ }^{62}$ Nurhata, "Naskah Muhammad Samman: Suntingan Teks Dan Analisis Tema" (Universitas Indonesia, 2011), 8.

${ }^{63}$ Seyyed Hossein Nasr, Tiga Madzhab Utama Filsafat Islam (Jakarta: Ircisod, 2006), 177.

${ }^{64}$ Haji Abdurrahman Ambodalle, Ada Tongeng-Tongengngé Ripannessana Pappéjeppué Ri Puang Mappancajié (Pare-Pare: Percetakan Khaeriyah, 1955), 27. 
vokal /i/, dan Muhammad melalui vokal /u/. ${ }^{65}$ Dalam konteks ini, mistik dipahami sebagai suatu kepercayaan bahwa manusia dapat berkomunikasi, bahkan bersatu dengan Tuhan melalui batin dalam sebuah meditasi (Simuh, 1995: 195). Hal ini tampak sama dengan paham wahdat al-wujud Ibn 'Arabi. Penganut wujudiyah terkemuka yang menjadi salah satu mata rantai utama jaringan ulama di Nusantara adalah Nur al-Din al-Raniri. Melalui alRaniri yang membaiat Syekh Yusuf al-Maqassari saat berada di Aceh, ${ }^{66}$ paham wujudiyah masuk ke Sulawesi Selatan seiring dengan perkembangan tarekat Khalwatiyah di wilayah tersebut. Oleh sebab itu, Tarekat Khalwatiyah Sammaniyah merupakan tarekat yang memiliki pengikut terbanyak di Sulawesi Selatan.

\section{PENUTUP}

Kutika Ugi' Sakke Rupa (KUSR) sebagai salah satu teks keagamaan yang memuat berbagai informasi-informasi berharga terkait jejak-jejak pengamalan ajaran tasawuf masyarakat Sulawesi Selatan abad ke-19. Pengetahuan alam (sains) lokal mengenai ilmu hitung kutika berkaitan erat dengan paham sufisme yang terealisasi melalui ajaran-ajaran tasawuf seperti wahdat al-wujud dan zikir-zikir tarekat yang menjadi bukti bahwa literatur tasawuf memiliki posisi tersendiri bagi masyarakat Sulawesi Selatan pada masa itu.

Di sisi lain, ilmu hitung Putika Pukulu' Jangé menjadi bukti lain bahwa sistem peredaran matahari terhadap bulan dalam realitas esensial heliosentrisisme Ibn Arabi diadopsi ke dalam metode hitung orang Bugis dengan caranya sendiri. teks KUSR ini merupakan teks profan yang pernah hidup di tengah masyarakat pada masanya. Naskah KUSR juga dimaknai sebagai upaya masyarakat Sulawesi Selatan dalam membangun memori kolektifnya secara integratif. Hal ini tampak pada teks KUSR yang melandasi transmisi pengetahuan ilmu falak dengan ilmu tasawuf sebagai sebuah kesatuan yang tak terpisahkan.

${ }^{65}$ Akhmar, Islamisasi Bugis: Kajian Sastra Atas La Galigo Versi Bottina I La Déwata Sibawa I Wé Attaweq, 475.

${ }^{66}$ Gibson, Narasi Islam Dan Otoritas Di Asia Tenggara Abad Ke-16 Hingga Abad Ke-21, 70. 


\section{DAFTAR PUSTAKA}

\section{Buku}

Abu, Hamid. Syekh Yusuf: Seorang Ulama, Sufi, Dan Pejuang. Jakarta: Yayasan Pustaka Obor Indonesia, 1994.

Achadiati, Ikram. Pengantar Penelitian Filologi. Jakarta: Manassa, 2019.

Akhmar, Andi Muhammad. Islamisasi Bugis: Kajian Sastra Atas La Galigo Versi Bottina I La Déwata Sibawa I Wé Attaweq. Jakarta: Yayasan Pustaka Obor Indonesia, 2018.

Al-Mu'min, Abdul Amir. At-Turats Al-Falaky 'Inda a'-Arab Wa Al Muslimin Wa Atsaruhu Fi Ilm Al-Falak Al-Hadits. Aleppo: Universitas Aleppo, 1991.

Ambodalle, Haji Abdurrahman. Ada Tongeng-Tongengngé Ripannessana Pappéjeppué Ri Puang Mappancajié. Pare-Pare: Percetakan Khaeriyah, 1955.

Anderson, Kathryn Gay. "The Open Door: Early Modern Wajorese Statecraft and Diaspora," 2003.

Assegaf. Sejarah Kerajaan Sadurangas Atau Kesultanan Pasir. Tanah Grogot: Pemerintah Daerah Tingkat II Pasir, 1992.

Azra, Azyumardi. Jaringan Ulama Timur Tengah Dan Kepulauan Nusantara Abad XVII Dan XVIII Akar Pembaruan Islam Indonesia. Depok: Prenadamedia Group, 2018.

Burckhardt, Titus. Mystical Astrology According to Ibn 'Arabi. Louisville: Fons Vitae., 2001.

Butar-Butar, Arwin Juli Rakhmadi. Filologi Astronomi. Purwokerto: UMP Press, 2017.

Enre, Fachruddin Ambo. Ritumpanna Wélenrénngé, Sebuah Episoda Sastra Bugis Klasik Galigo. Jakarta: Yayasan Obor Indonesia, 1999.

Gibson, Thomas. Narasi Islam Dan Otoritas Di Asia Tenggara Abad Ke-16 Hingga Abad Ke-21. Makassar: Ininnawa, 2012.

Hadrawi, Muchlis. Assikalaibineng, Kitab Persetubuhan Bugis. Makassar: Ininnawa, 2017. 
Ibn al-'Arabi, Muhyiddin. Al-Futuhat Al-Makkiyah Jilid II. Edited by Harun Nur Rosyid. Yogyakarta: Darul Futuhat, 2018.

Kesuma I.C, Andi Ima. Politik Ranjang Bugis Makassar. Makassar: Universitas Negeri Makassar, 2010.

Mansyur. "Diaspora Suku Bugis Di Wilayah Tanah Bumbu, Karesidenan Borneo Bagian Selatan Dan Timur Tahun 18421942," 2012.

Matthes, B F. Makassarsche En Boeginesche Kotika's. Leiden University Libraries: Sutherland, 1868.

Mattulada. Latoa, Satu Lukisan Analitis Terhadap Antropologi Politik Orang Bugis. Ujung Pandang: Hasanuddin University Press, 1995.

—. Menyusuri Jejak Kehadiran Makassar Dalam Sejarah. Yogyakarta: Ombak, 2011.

Mūsā, Hishām al-Kāmil Hāmid. Fath Al-'Allām Bi Sharh Manzūmati 'Aqīdati Al-'Awwām. Cairo: Dār el-Manār, 2013.

Nabba, Andi Palloge. Sejarah Kerajaan Tanah Bone. Makassar: Yayasan al-Mu'allim Sulawesi Selatan, 2006.

Nasr, Seyyed Hossein. Tiga Madzhab Utama Filsafat Islam. Jakarta: Ircisod, 2006.

Paeni, Mukhlis. Katalog Induk Naskah-Naskah Nusantara; Sulawesi Selatan. Jakarta: Arsip Nasional Republik Indonesia, 2003.

Pelras, Christian. Manusia Bugis. Jakarta-Paris: Nalar bekerja sama dengan Forum, Ecole Francaise d'Extreme-Orient (EFEO), 2006 .

Pudjiastuti, Titik. Sumber-Sumber Tertulis Indonesia Tengah, Kajian Kodikologis, Filologis, Linguistis, Historis, Dan Budaya: Kalimantan Timur Dan Utara. (belum diterbitkan), n.d.

Rahmatia, A W. "Kutika Suku Bugis Di Kalimantan Timur: Kajian Filologi Dan Gagasan Ekofenomenologi," 2020.

Reid, Anthony. "Pluralisme Dan Kemajuan Makassar Abad Ke-17." In Kuasa Dan Usaha Di Masyarakat Sulawesi Selatan. Makassar: Ininnawa, 2019.

Young, Cho Tae. Aksara Serang Dan Perkembangan Tamaddun Islam 
Di Sulawesi Selatan. Yogyakarta: Ombak Press, 2012.

Zoetmulder, P J. Kalangwan, Sastra Jawa Kuno Selayang Pandang. Jakarta: Djambatan, 1985.

\section{Jurnal}

Gunawan, Fahmi. "Good and Teribble Days Symbols in Pananrang Manuscript: A Cultural Linguistics Approach." In Proceedings 2nd International Seminar on Linguistics (ISOL II), 94-101. Padang: Universitas Andalas, 2015.

Kathryn, Robinson, and Mukhlis PaEni. "Living Through Histories: Culture, History and Social Life in South Sulawesi." Journal of Southest Asian Studies 32, no. 03 (1998): 469-72.

Koolhof, Sirtjo. “The 'La Galigo'; A Bugis Encyclopedia and Its Growth." Bijdragen Tot de Taal-, Land- En Volkenkunde 155, no. 3 (1999): 362-87.

Noorduyn, J. Een Boeginees Geschriftje over Arung Singkang” Dalam Bijdragen Tot de Taal-, Land- En Volkenkunde. Leiden: KITLV \& Royal Netherlands Institute of Southeast Asian and Caribbean Studies, 1953.

Rajab, Hadarah. "Implementasi Nilai-Nilai Sufisme Tarekat Naqsabandiyah Di Sulawesi Selatan." Ulumuna: Jurnal Studi Keislaman XIV (2010): 341-68.

Ridhwan. "Development of Tasawuf in South Sulawesi." QIJIS (Qudus International Journal of Islamic Studies) 5 (2017): 2946.

Shaharir, B.M.Z. "Kosmologi Malayonesia Yang Terungkap Dalam Bahasa Melayu." Jurnal Peradaban 9 (2016): 11-31.

_. "Rolled up Bugis Stories: Marriage Advice and The Tale of The Parakeet." Review of Indonesian and Malaysian Affairs 43, no. 1 (2009): 189-208.

Tol, Roger. "Bugis Kitab Literature. the Phase-out of a Manuscript Tradition." Journal of Islamic Manuscripts 6, no. 1 (January 1, 2015): 66-90. https://doi.org/10.1163/1878464X-00601005.

Ubaedillah, Achmad. "The Rise of The Khalwatiyah Samman Sufi 
Order in South Sulawesi: Encountering The Local, Escaping The Global.” Studia Islamika 24 (2017): 213-43.

Yusmar, Syarifuddin. "Penanggalan Bugis-Makassar Dalam Penentuan Awal Bulan Kamariah Menurut Syariah Dan Sains." Jurnal Hunafa 5, no. 3 (2008): 265-86.

\section{Skripsi, Tesis, dan Disertasi}

Amir, Amrullah. "Sejarah Masyarakat Melayu Di Sulawesi Selatan 1600-1942: Identiti Dan Autoriti." Universiti Kebangsaan Malaysia, 2015.

Gardiner, Noah D. "Esotericism in a Manuscript Culture: Ahmad AlBuni and His Readers Through the Mamluk Period." University of Michigan, 2014.

Nurhata. "Naskah Muhammad Samman: Suntingan Teks Dan Analisis Tema." Universitas Indonesia, 2011. 